\title{
Kanıt Temelli Tarih Öğretiminde Ahlaki İkilem: Eylem Araştırması
}

\section{Moral Dilemma in Evidence Based History Teaching: Action Research}

\author{
Halil EKŞİ, Prof. Dr. \\ Marmara Üniversitesi, Atatürk Eğitim Fakültesi, Türkiye. \\ h.eksi70@gmail.com \\ https://orcid.org/0000-0001-7520-4549 \\ H. Yavuz YAŞAR, Sorumlu Yazar, Doktora Öğrencisi. \\ Marmara Üniversitesi, Atatürk Eğitim Fakültesi, Türkiye. \\ yavuz_yasar1520@hotmail.com \\ https://orcid.org/0000-0003-0213-6502
}

\author{
ISSN: 1303-880X \\ e-ISSN: 2667-7504 \\ http://ded.dem.org.tr
}

Makale Türü / Article Type: Araştırma Makalesi / Research Article Geliş Tarihi / Received Date: 14.01.2020 Kabul Tarihi / Accepted Date: 22.05.2020 Yayın Tarihi / Published Date: 25.06.2020

Tr/En: $\mathrm{Tr}$

Intihal / Plagiarism: Bu makale, en az iki hakem tarafindan incelendi ve intihal içermediği teyit edildi. / This article has been reviewed by at least two referees and scanned via a plagiarism software.
Attf/Citation: Ekşi, H. ve Yaşar, H.Y. (2020). Kanıt temelli tarih öğretiminde ahlaki ikilem: Eylem araştırması. Değerler Eğitimi Dergisi, 18 (39), s. 339-375. https://doi.org/10.34234/ded. 674957 
Öz: Geçmişte yaşanmış birtakım olayları ve olguları ele alan tarih dersi muhteviyatında insanlığa ait farklı değer ve yargıları da barındırmaktadır. Bu tecrübelerin bir bütünü olan tarih dersinin öğrencilerdeki değer ve yargı çeşitliliğini arttırması beklenmektedir. Tarih derslerindeki muhtelif değer ve yargıların varlığı Kohlberg'in ahlaki ikilemi ile bazı benzerlikler göstermektedir. Dolayısıyla Kohlberg'in ahlak gelişimi ile benzer özellikler taşıyan tarih derslerinin öğrencilerin ahlaki muhakeme becerilerini nasıl etkilediği, incelemenin esas konusu olmuştur. Çalışma nitel araştırma yöntemlerinden eylem araştırmasından faydalanılarak yapılmıştır. Bu bağlamda lise son sınıf ve üniversite hazırlık öğrencilerinden 10 kişiyle kanıt temelli tarih dersi işlenmiştir. Kardeş katli, Varlık vergisi ve Haçlı seferleri konuları esas alınarak toplamda 3 tane tarih dersi yapılmıştır. Bu derslerde öğrencilerin bahsedilen konularla ilişkili tarihsel olaylara dair yorumlarını şeffaf bir ortamda ifade edebilmelerine olanak tanınmıştır. Böylelikle etkileşimli ve demokratik bir ortam oluşturulmaya çalışılmıştır. Yapılan kanıt temelli tarih derslerinde öğrencilerin yorumları, hal ve tavırları kayıt altına alınmıştır. Elde edilen veriler gözlem ve doküman analizi kullanılarak yorumlanmıştır. Verilerin değerlendirilmesi sonucunda tarih derslerinin öğrencilerdeki ahlaki muhakeme becerilerini geliştirebileceğine yönelik olumlu sonuçlar elde edilmiştir.

Anahtar Kelimeler: Tarih öğretimi, Ahlaki ikilem, Kohlberg, Lise öğrencileri, Eylem araştırması.

\section{\&}

Abstract: The history lesson, which deals with a number of events and facts in the past, also includes different moral judgments and human values. The history lesson, which is the accumulation of these experiences, is expected to increase students' acquisition of variety of values and judgments. The existence of different values and judgments in history lessons shows some similarities with Kohlberg's moral dilemma. Therefore, the main subject of the study is how history lessons with similar characteristics to Kohlberg's moral development affect students' moral reasoning skills. The study was carried out using qualitative research methods and action research. In this context, ten students from senior high school and university preparatory school students have been taught evidence-based history lessons. A total of 3 history lessons were conducted based on the Sibling Mass, Wealth Tax and Crusades. In these lessons, students were given the opportunity to express their comments on historical events related to 
the aforementioned topics in a transparent environment. Thus, an interactive and democratic environment was tried to be created. Students' comments, manners and behaviors were recorded through evidence based history lessons. The data obtained were interpreted using observation and document analysis. As a result of evaluating the data, positive results were obtained that history lessons could improve moral reasoning skills in students.

Keywords: History teaching, Moral dilemma, Kohlberg, High school students, Action Research.

(The Extended Abstract is at the end of the article)

\section{Giriş}

Okulun amaçları günümüze dek ulaşan tarihsel süreçte pek çok tartışmanın odak noktası olmuş, zamanın ruhuna ve ihtiyaçlarına göre şekillenmiştir. Modernizmle beraber okulun amaçlarında büyük değişimler olmuş ve okul her zamankinden daha etkili, yaygın ve şekillendirici olmuştur (Gündüz, 2013). Modern öncesi Tanrı-kul münasebetlerinin yerini modern dönemde toplum-birey ilişkisi almaya başlamıştır (Durkheim, 2014). Modern eğitim paradigmasına hizmet eden davranışçı pedagoji; tek tipçi, devamlılığa ve zorunluluğa dayalı, yaygın, jakoben, sekülerleştirilmiş ritüellerle çevrili, sonuç ve istendik davranışları kazandırma odaklı bir eğitim olarak şekillenmiştir (Giorgetti, 2016). Bilim paradigmasında olan değişimler, bilgi ve onun üretimine ilişkin ortaya çıan yeni görüşler, II. Dünya Savaşından sonra edinilen tecrübeler neticesinde okulun amaçlarına yönelik eleştiriler de giderek arttı. Okulun muktedirin kendi iktidarını sürdürmek için kullandığı ideolojik bir aygıt olarak yorumlayanların eleştirileri yükselmeye başlamıştır (Althusser, 2016; Ferrer, 2014). Freire de okulu nakilci ve aktarmacı olarak nitelendirerek bunu "bankacı eğitim" adı altında değerlendirmiştir (Freire, 2017). Illich ise okulun, araçsal aklın pratik ve çıkarcı amaçlarına hizmet ettiğini ifade etmiştir. Okulun, üretim hizmetlerine eleman yetiştiren bir modele dönüşerek asıl amacını yitirip bireyleri sertifikalandıran bir yere döndüğünü söyler. Artık öğrenciler ve ebeveynler için eğitimden çok diploma almak ve üretime dâhil olmak önemli hale gelmiştir (Illich, 2016). Pek çok eleştiri çerçevesinde eğitim bireyin ilgi ve yeteneklerini kendisinin keşfettiği, süreç odaklı, bilgiyi bireyin inşa ettiği, heterojen bir sürece geçiş yapmıştır. 
Modernizmin paradigmasıyla şekillenen okulun işlevleri içerisinde tarih öğretimi de yerini almıştır. Tarih dersleriyle müşterek bir ülkü etrafında toplanmış bir toplum inşa edilmek amaçlanmıştır. Toplumu birbirine bağlayan bu ülkü modernizmin etkisiyle kaynağını dinden değil tarihten almış bir mit etrafında şekillenmiştir. $\mathrm{Bu}$ toplumsal bağın muhafazası da bizzat toplumun kendisine tevdi edilmiş ve bu amaçla oluşturulan militarist nitelikler tarihsel bağlarla da kuvvetlendirilmiştir. Sınırları belirlenmiş ortak bir fikir etrafında buluşan bu topluma millet denilmiş ve tarih eğitimine bunun oluşturulmasında önemli misyon yüklenmiştir (Üstel, 2004). Tarih eğitimi de okul olgusunun değişimiyle beraber dönüşmeye başlanmıştır. Tarih eğitimi, tarihsel düşünme becerilerini kullanarak sosyal problemlerin üstesinden gelme, öteki ile olumlu ilişkiler kurabilme, bireyin kendisini gerçekleştirebilmesi, yetenek ve kabiliyetlerini ortaya çıararak tarihsel inşa sürecini gerçekleştirebilmesi çerçevesinde gelişme göstermiştir (Demircioğlu, 2014). Tarih eğitiminde, öğrencileri küçük bir tarihçi gibi değerlendiren ve ona yapılandırılmış bir biçimde birinci ve ikinci elden kaynaklar sunarak kendi tarihsel inşa süreçlerini destekleyen kanıt temelli yaklaşım ortaya çıkmıştır (Stradling, 2003; Nichol, 1991; Kabapınar, 2019). Çocuk kendisine sunulan kanıtları iş birlikli öğrenme eşliğinde tarihsel imgelemi kullanarak yorumlamaktadır (Collingwood, 2019). Burada öğrencilerin tarihsel olaylarla kurmuş olduğu ilişkiler şahsi olduğu kadar sınıf içerisinde iş birlikli olması dolayısıyla da müşterektir. İki taraflı bir bilişsel süreç olup tek tipçi anlayıştan uzaktır.

Bireyin tarihle kurduğu ilişki ve ahlaki ikilemle onun kimliği, kültürü ve sınıfsal yapısı yakından ilişkilidir. Bu nedenle kanıt temelli eğitim sürecinde bireylerin tarihsel olaylar üzerinde yapacakları yorumlar, tartışmalar ve ulaşacakları kanaatler onların ahlaki bakış açılarının anlaşılması açısından ipuçları sunmaktadır. Bu nedenle tarihi olaylar seçilirken ahlaki ikileme kaynaklık edebilecek zıt ve tartışmalı tarihsel olaylar tercih edilmelidir. Bu bağlama uygun olarak seçilen tarihsel olayların uygulanması sonucunda elde edilen veriler yorumlanırken Kohlberg'in kuramından faydalanılabilir (Kohlberg, 1963; Kohlberg 1964; Kohlberg, 1973; Modgil ve Modgil, 2011). Kohlberg'in ahlaki ikilemi Aristo'ya dayanan adalet problemini üç ana şekilde incelemektedir. Paylaşımsal, düzenleyici ve düzeltici adalet problemleri olarak sınıflandırılmaktadır. Paylaşımsal adalet, eşit haklar, toplumsal eşitlik gibi unsurları ihtiva eder. Düzenleyici adalet sözleşme, uzlaşma gibi konuları işlemektedir. Düzeltici adalet ise yaşanan olumsuz olaylardan sonra bunları düzenleme, onarma amacını kapsamaktadır (Çiftçi, 2003). Kohlberg'e göre ahlak, bilişsel bir süreçtir ve birey bilişsel yete- 
neklerini kullanarak evrensel ölçütlere uygun biçimde yargıda bulunabilmektedir. Kohlberg, ahlak kuramında alttan üste doğru gelenek öncesi düzey, geleneksel düzey ve gelenek sonrası düzey olarak incelemiştir. Gelenek öncesi düzeyin içerisinde itaat ve ceza ile saf çıkarcılık, geleneksel düzeyin içerisinde iyi çocuk ile kanun ve düzen, gelenek sonrası düzeyin içerisinde ise sosyal sözleşme ve evrensel ahlak ilkeleri bulunmaktadır (Rubin ve Trotter, 1977). Kolhberg insanın hangi basamağa ne zaman ulaşacağını belirleyen dört temel unsurdan bahseder. Bunlar genetik kalıtımın ön plana çıktığı mantıki sorgulama kapasitesi, çevresel ve genetik kökenden kaynaklanan bireyin motivasyon durumu, bireyin sosyal rolleri öğrenme durumu ve içerisinde yaşadığı adalet biçimidir. İnsanlar bunlar arasında ulaşabildikleri en yüksek sorgulama basamağını tercih ederler. Herkesin basamakları geçiş hızı bireysel farklılıklar gösterebildiği gibi bireyin ahlaki gelişiminin de bir noktada sabitlenmesi mümkündür (Çinemre, 2012).

Kohlberg'e göre ahlaki bilinç ve ahlaki davranış bireyin toplumla kurmuş olduğu karşı1lıklı etkileşim sonucunda gelişir (Çiftçi, 2003). Kohlberg iyinin bilgisinin bireyde bulunduğunu ancak bunun da Sokratik tarzda açığa çıkarılması gerektiğini söyler. Kohlberg, kültürün ahlak gelişimindeki etkisini de tamamen reddetmez. Bu bağlamda bireyin zihninin çevreyle kurmuş olduğu ilişki onun ahlaki düşüncesini de etkiler. Bireyin sosyal çevreyle kurmuş olduğu etkileşimin çeşitliliği, bireyin kompleks düşünme biçiminin gelişmesini sağlar. Bireyin toplumla kurduğu münasebetler onun ahlak gelişiminde önemlidir (Y1lmaz, Bahçekapılı ve Sevi, 2019). Bu doğrultuda tarih eğitiminde iş birlikli tutumla tarihsel olaylar hakkındaki yargılar karşılıklı etkileşim içerisinde olacaktır. Kohlberg'in kuramı ahlaki bilinç ve ahlaki davranış arasındaki bağlantıyı yeterince kuramadığı yönünde eleştirilmiştir. Zira bireyin ahlaki bilinci ne olursa olsun ahlaki davranışı ondan farklı olabilir (Çinemre, 2012). Bu nedenle incelemede ahlaki yargı kısmı üzerine bir tasvir yapılmıştır.

Kohlberg ahlaki yargılama yeteneğinin bireye sunulacak çatış1k durumlara karşı ulaştığ çözümlerle tespit edilebileceğini ifade eder. Birey çatışı duruma olabildiğince farklı perspektiflerden bakarak en adil çözümü bulmalıdır (Çiftçi, 2003). Ahlaki ikileme müsait, çatışık tarihsel olaylar üzerinden yapılacak eğitimle bireylerin tarihi olayları yorumlaması üzerinden ahlaki yargılarını tespit ve geliştirilmesine imkân sağlanmaktadır.

Tarih, modernizm sürecinde yeni bir toplum inşa etmede harç vazifesi görmüştür. Bireyin toplumsal aidiyetinde, kendisini tanımlamasında yani kimliğinin oluşumunda tarih ve tarihi algılama biçimleri önemli bir yer işgal etmiştir. 
Bireylere sunulan tarihi olayların yorumlanış ve ele alınış şekliyle bireyin aidiyet kurduğu kimlik yakından ilişkilidir. Bireylerin sahip olduğu kimliklerle ortak tarih anlatısı üzerinden öteki inşası modernizmle hayatımıza ciddi şekilde etki etmiş olan bir olgudur (Pamuk, 2014). Tüm bunların sonucunda bireyin tarihsel olaylara karşı verdiği yargılar ve değerlendirmeler, onun aidiyet hissettiği kimlik ve kültürle ahlaki yargısı arasındaki ilişkiyi de gösterebilecektir. Zira Kohlberg ahlaki davranışla kültürün birbiriyle ilişki içerisinde anlaşlabileceğini ifade etmektedir (Çiftçi, 2003). Kohlberg ahlak kuramında tepeden inmeci, nasihatçi bir anlayışa karşı çıkmıştır. Aktarımın değil keşfetmenin önemi üzerinde durmaktadır. Ahlak gelişiminde bireylerin kurallara doğrudan uymasının değil karar alma mekanizmasında aktif olarak bulunmasının ve problem çözme becerisinin geliştirmesinin önemine inanır. Kohlberg ahlaki değerlerin içselleştirilmesinde de daha çok bilişsel süreçleri ön plana çıkartmaktadır (Çinemre, 2012). Ayn zamanda mutlak değerlerin yerine, herkesin kimliğine uygun olarak benimsediği ahlaki yargıları toplumsal huzura uygun olarak özgür biçimde ifade edip yaşayabilmesi gerektiğini ifade etmektedir. Bu durum ahlakın mutlak yasalardan uzak olduğunu bizlere göstermektedir. Ahlaki ikilemde bir olaydaki farklı ahlaki yargılar insanların bakış açısına sunulur. İnsanların tercihleri ahlaki yargılarıyla doğrudan ilişkilidir. Bunun yanı sıra farklı bakış açılarına, yaşamlara, kimliklere saygı duyulmasına ve toplumsal demokrasinin, empatinin gelişmesine katkı sunar (Ekşi ve Katılmış, 2016). Kohlberg, ahlaka ilişkin eğitimin hedeflerini "insanların düşünce yeteneklerini, gelişimlerine uygun şekilde harekete geçirmek ve ahlaki problemlerini çözmek için kendilerine daha yeterli ve kompleks düşünme becerileri kazandırmak" olarak betimlemektedir (Çinemre, 2012).

Kohlberg'in ahlaki basamaklarının bireylerin vermiş olduğu cevapların altında yatan ahlaki sorgulamanın anlaşılması önemlidir. Bu ahlaki sorgulama sürecinin en iyi biçimde ortaya çıkmasını sağlayan durum ahlaki ikilemdir. $\mathrm{Bu}$ nedenle ahlaki ikilem ötekinin anlaşılmasını kolaylaştıran bir süreçtir. Ancak bazı araştırmacılara göre hipotetik ikilemlerin ortaya koyduğu sonuçlar ahlaki sorgulama süreçlerinin anlaşılması için gerçek yaşam ikilemleri kadar etkili olamamaktadır. Günlük tecrübe ve problemlere daha yakın olan ahlaki ikilemlerin seçilmesi incelemenin sıhhati açısından önemlidir (Enright, Lapsley ve Olson, 2011; Pearson, 2011). Bu bağlamda tarihi olayların sunumu ahlaki sorgulama süreçlerinin anlaşılabilmesine katkı sunmaktadır. Ahlaki ikileme dair tartışmaları başlatmak için görsel malzemelerin olabildiğince çok kullanılması, ikilem tartışmalarının doğrudan sınıfta sunulması ve yukarıda da sözü edildiği 
gibi ikileme dair olayların gerçek hayattan seçilmesi bazı önemli hususlardır. Tartı̧̧ma esnasında öğrencilerin ahlaki ikileme dair durumu net olarak anladıklarından emin olunması ve gerektiğinde öğretmenin onlara tarafsızca rehberlik etmesi gerekmektedir. Verilen cevapların altında yatan nedenlerin öğrenilmesi ahlaki yargının anlaşılması açısından önemlidir. Bu nedenle öğrencilerin verdikleri cevaplarda yeri geldiğinde irdelenerek anlaşılmaya çalışılmalı ve nedenleri üzerine durulmalıdır. Bu noktada öğrencinin kurduğu ahlaki bağlamı genel hatlariyla anlama veya daha derinlemesine sorular sormak yoluyla nedenlerine inmek gerekebilir. Ahlaki ikilem bağlamında inşa edilen tartışma öğrencilerin iş birliği ve sosyal katılıma, demokratik değerleri anlayıp kimliklere saygı duymas1 ve sağlıklı kimlik gelişimini sağlaması, inceleme bağlamında tarih ve tarihsel düşünme becerileri hakkında bilgi edinmesi, öz benliğinin gelişmesi ve muhakeme becerilerinin gelişmesine katkıda bulunur (Rich, 2011; Wilson, 2011; Sullivan, 2011).

Kohlberg'e göre ahlak eğitiminde yetersiz üç konu bulunmaktadır. Bunlar içerikten çok biçime vurgu yapılması, iyi kavramından çok bireyin yükümlü olduğu hak ve görevlere vurgu yapılması, davranıştan çok ahlaki muhakemeye odaklanılmasıdır (Çinemre, 2012). Özellikle ahlaki yargı ile ahlaki davranış arasında oluşabilecek farklılık kuramın eleştirilen noktalarından biridir. Zira insanların karşılaştıkları ahlaki ikilemlerde verdikleri teorik kararlarla pratik hayatta verecekleri kararlar arasında her zaman benzerlik bulunmamaktadır. $\mathrm{Bu}$ nedenle bireylerin ahlaki ikilemlerde yaptıklarıyla söyledikleri arasındaki muhtemel uyumsuzluk Kohlberg kuramının eleştirilen yerlerinden olmuştur.

Milli Eğitim Bakanlı̆̆ı'nın Değerler Eğitimi Yönergesinin 1. maddenin D kısmında öğrencilere bireysel ve toplumsal sorunları tanıma ve sorunlara çözüm yolları arama alışkanlığı kazandırmak amacı, tarih öğretimi ve Kohlberg'in ahlak kuramıyla doğrudan uyumludur (MEB). Zira kanıt temelli tarih eğitimi tarihsel düşünme becerilerini geliştirmeyi ve problem çözmeyi bir amaç edinirken Kohlberg'in, ahlak gelişim ve bilişsel gelişim arasında kurmuş olduğu ilişki açıktır. Yine mezkûr yönergenin 1. maddesinin I kısmında "değerlere karşı duyarlılık oluşturma ve onları davranışa dönüş̧ürme konusunda yardımcı olmak" amacı da çalışmayla örtüşmektedir. İncelemede ahlaki ikilem tartışmalarına zemin hazırlayabilecek tarihi olaylar kanıt temelli öğretimle verilerek çocukların ahlaki yargıları anlaşılmaya çalışılmıştır. Bu bağlamda problem sorusu "kanıt temelli tarih öğretimiyle yapılandırılan tarih dersinde Kohlberg'in ahlaki kuramına göre öğrencilerin ahlaki muhakeme becerileri nasıl etkilenmektedir?" olarak belirlenmiştir. 


\section{Yöntem}

İnceleme, nitel araştırma yöntemlerinden faydalanılarak yapılmıştır. Nitel araştırmada konu derinlemesine analiz sürecini kapsamaktadır. İncelemede olguları anlamlandırma ve yorumlama çabası içerisine girilmiştir. Bu nedenle bulguları tasvir eden, problem durumunu anlamlandıran ve derinlemesine çözümleyen bir süreç olan nitel araştırma yöntemlerinin (Yıldırım ve Şimşek, 2013; Neuman, 2013; Punch, 2005; Creswell, 2013; Patton, 2014, Balc1, 2011) kullanilması tercih edilmiştir. Nitel araştırma yöntemleri olgular arasındaki nedensellik ilişkilerini kültür, tarih, sosyoloji, etnografya gibi pek çok açıdan derinlemesine incelendiğinden (Yıldırım ve Şimşek, 2013) araştırma konusuyla daha uyumludur. Aynı zamanda nitel araştırma inşacı yapısıyla araştırmacının yeni kuramlar ortaya atmasına müsaittir. Bu nedenle nitel araştırma yönteminde araştırmac1nın incelediği alana karşı yaklaşım tarzı büyük öneme sahiptir (Büyüköztürk, Kılıç Çakmak, Akgün, Karadeniz, Demirel, 2012).

Araştırmada, nitel araştırma yöntemlerinden eylem araştırması kullanılmıştır. Eylem araştırmasıyla sosyal olayların sorunları belirlenir veya mevcut durum geliştirilmeye, onarılmaya çalışılır. Eylem araştırması, ulaşılan bulgulara benzer sosyal durumlar karşısında da çözüm sunan, yeniden düşündüren bir yapıdadır (Büyüköztürk, K1lıç Çakmak, Akgün, Karadeniz, Demirel, 2012; Patton, 2014). Eylem araştırması inceleme sonucunda bulgular uygulamanın yönünü değiştirebilir ve araştırmaya katılan sosyal durumun içindeki kimseler hakkında daha derinlemesine bilgi ve deneyim elde edilir (Patton, 2014). Yapılan araştırma da mevcut tarih eğitimiyle ilgili durumu değerler eğitimi kapsamında yeniden ele almakta, onu düzenlemekte ve eğitime katkı sunmaya çalışmaktadır.

Kohlberg ahlak kuramında bilişsel süreçlerin tetiklenmesiyle daha üst ahlaki basamaklara çıkılabileceğini düşünmektedir (Kohlberg ve Turiel, 1971; Slavin, 2017). Eylem araştırması da mevcut durumun onarılması, gözden geçirilmesi veya geliştirilmesi gibi amaçları barındırdığından ahlaki basamaklar arası geçişkenliğin örnek tarihi olaylar yoluyla sağlanması eylem araştırmasıyla yakından ilişkilidir. Bu sayede etkinlik öncesinde bireyin ahlaki basamağıyla etkinlik sonrası bireyin ahlaki basamağı arasında değişme, ahlaki yargısında üst basamaklara dönük bir gelişme, daha esnek, empatik, çok boyutlu düşünebilmek bulguların elde edilip edilmemesi gözlemlenecektir. Tüm bunların neticesinde, bireylerin farkl1lıklara açık olabilmesine, ötekiyle empati kurabilmesine, demokratik sosyal ilişki ve becerilere sahip olabilmesine, toplumla sağlıklı iliş- 
kiler kurabilen ve sosyalleşebilen bir birey olabilmesine katkı sunulması beklenmektedir. Kohlberg'in ifade ettiği ahlaki basamakların bireye kazandırılmasında ahlaki ikilemi ortaya koyan ve bireyin bilişsel yeteneklerini kullanmasını teşvik eden etkinlik ve stratejiler bu bağlamda ele alınabilir (Ekşi ve Katılmış, 2016).

\section{Çalışma Grubu}

Örneklem, evreni olabildiğince bütüncül biçimde temsil etmelidir. Bu bağlamda araştırmada amaçlı örnekleme kullanılmıştır. Amaçlı örneklem kapsamında tipik durum örneklemesi esas alınmıştır (Yıldırım ve Şimşek, 2013). Türkiye'de eğitim olanaklarının genelini yansıttı̆̆g düşünülen ortalama, standart bir okul çalışma için tercih edilmiştir. Bu amaçla İstanbul Beşiktaş’ta özel bir lisede çalışma yürütülmüştür. Araştırmadaki öğrenci grubu ise bu okulun son sınıf öğrencileri ve üniversiteye hazırlık dersi gören 10 kişilik gruptur. Çalışma grubunda öğrenciler Tablo 1'de gösterilmiştir:

\begin{tabular}{llll}
\hline Tablo 1: Çalışma Grubuyla Alakalı Bilgilerin Yer Aldı̆̆ Tablo & \\
\hline Öğrenci & Doğum Yılı & Cinsiyet & Semt Bilgisi \\
\hline Ö1 & 2001 & Erkek & Beşiktaş \\
\hline Ö2 & 1998 & Erkek & Beşiktaş \\
\hline Ö3 & 2001 & Erkek & Beşiktaş \\
\hline Ö4 & 1999 & Kadın & Beşiktaş \\
\hline Ö5 & 2000 & Erkek & Beşiktaş \\
\hline Ö6 & 2001 & Kadın & Beşiktaş \\
\hline Ö7 & Kadın & Beşiktaş \\
\hline Ö8 & 2001 & Erkek & Beşiktaş \\
\hline Ö9 & 2001 & Erkek & Beyoğlu \\
\hline Ö10 & 2001 & Kadın & Beyoğlu \\
\hline
\end{tabular}

\section{Veri Toplama Araçları}

Veri toplama araçları olarak gözlem ve doküman analizi kullanılmıştır. Kardeş katli, Haçlı seferleri ve Varlık vergisi kanıt temelli etkinlik biçiminde öğrencilere sunulmuştur. Etkinlikler esnasında öğrencilerin hal, hareket, jest ve mimikle- 
ri gözlemlenmiş ifadelerse ses kayıt cihazıyla kayda alınmıştır. Bu kayıtlardan elde edilen dokümanlar incelenmiştir. Etkinlik sırasında ortaya çıkan durumlar hakkında araştırmacı gözlemlerine dayanan bazı notlar da almıştır.

Verilerin toplanması esnasinda faydalanılan tarihi konulardan 1. ve 2. elden görsel, yazılı kaynaklar seçilerek ve yapılandırılarak kanıt temelli tarih eğitimine uygun hale getirilmiştir. Tarihi konu olarak ahlaki ikilemin ortaya çıkmasına zemin hazırlayabilecek Haçlı seferleri, Kardeş katli ve Varlık vergisi konuları seçilmiştir. İlk uygulama olarak Kardeş katli seçilmiş ve 30 Aralık 2018 tarihinde 75 dakika süren bir etkinlik uygulanmıştır. Etkinlikte Kardeş katline dair tarihsel örnekler olabildiğince objektif olarak öğrencilere "kanıt" adıyla sunulmuştur. Kardeş katli konusuna ilişkin etkinlikte toplam 19 adet kanıt bulunmaktadır. Bu kanıtların her birinin altında "kanıt sorgulama" başlığı içerisinde sorular yerleştirilmiştir. Her kanıtın altında farklı sayı ve nitelikte yer alan toplam 51 adet kanıt sorgulama sorusu öğrencilere yöneltilmiştir. Bu sorular öğrenciler tarafından tartışılmıştır. Araştırmacı burada tartışmaya müdahil olmamış ancak onu yönlendirmiş ve tartışmanın gidişatına göre gerektiğinde ek sorular sormuştur. İkinci olarak Varlık vergisi konusu seçilmiş, 11 Ocak 2019 tarihinde etkinlik uygulanmış ve 72 dakika sürmüştür. Varlık vergisi konusuna ilişkin etkinlikte ise toplam 19 adet kanıt bulunmaktadır. Her kanıtın altında farklı sayı ve nitelikte yer alan toplam 27 adet kanıt sorgulama sorusu öğrencilere yöneltilmiştir. Kanıtlar öğrencilere yöneltilen kanıt sorgulama soruları ışığında araştırmacının rehberliğiyle tartışılmıştır. Son uygulamaysa Haçlı seferleri konusunda 24 Ocak 2019 tarihinde yapılmış ve 70 dakika sürmüştür. Haçlı seferleri konusuna ilişkin etkinlikte ise toplam 31 adet kanıt bulunmaktadır. Her kanıtın altında farklı sayı ve nitelikte yer alan toplam 55 adet kanıt sorgulama sorusu öğrencilere yöneltilmiştir. Kanıtlar, kanıt sorgulama soruları doğrultusunda öğrenciler tarafından tartışılmış, araştırmacı bu sürece rehberlik etmiştir. Her ders etkinliğine yer alan kanıtlara ilişkin kanıt sorgulama sorularının niceliksel dağılımı Tablo 2'de belirtilmiştir. Her bir etkinlik ortalama 2 ders süresini kapsayacak biçimde tasarlanmıştır. Katılımcıların tarihi kanıtlar üzerinden kendilerine yöneltilen sorulara verdikleri cevaplar, tartışmalar, değerlendirmeler, jest ve mimikleri, ses kayıt cihazı ve not defterine kaydedilmiş ve ardından yazıya aktarılmıştır. Kardeş katline ilişkin 1 saat 5 dakikalık, Varlık vergisine ilişkin 1 saat 12 dakikalık, Haçı seferlerine ilişkin 1 saat 10 dakikalık ses kayıtları elde edilmiştir. Elde edilen verilerin süreç içerisindeki değişim ve benzerlikleri çalışmanın bulguları ve sonuçları açısından önemlidir. Katılımcıların yukarıda belirtilen tarihi konular hakkında vermiş oldukları cevaplar değerlendirilmiştir. Öğretmen bu süreçte bir 
gölge, kılavuz konumunda olmuştur. Öğretmen katılımcıların görüşlerini rahat ve özgür biçimde ifade edecekleri ortamı sağlamak, tarafsızlığını muhafaza etmek, katılımcıları teşvik etmek ve tartışmayı kontrol etmek durumundadır (Ekşi ve Katılmış, 2016).

Tablo 2: Etkinliklerin İçeriğine Dair Niceliksel Dağılım

\begin{tabular}{|c|c|c|c|}
\hline Etkinlik & Kanitlar & Kanıt Sorgulama Soruları & Ders Süresi \\
\hline \multirow{12}{*}{$\begin{array}{l}\text { Kardeş } \\
\text { Katli Etkinlik } \\
\text { Örneği }\end{array}$} & Kanıt 1 & $1,2,3$ & \multirow{12}{*}{1 saat 5 dakika } \\
\hline & Kanit 2, 3 & $1,2,3,4$ & \\
\hline & Kanit 4 & $1,2,3,4,5,6,7$ & \\
\hline & Kanit 5 & $1,2,3,4$ & \\
\hline & Kanit 6, 7 & $1,2,3,4$ & \\
\hline & Kanit 8 & $1,2,3,4,5$ & \\
\hline & Kanit 9, 10 & $1,2,3,4$ & \\
\hline & Kanit $11,12,13$ & $1,2,3,4,5$ & \\
\hline & Kanit 14 & 1,2 & \\
\hline & Kanit 15,16 & $1,2,3,4$ & \\
\hline & Kanit 17 & $1,2,3,4$ & \\
\hline & Kanit 18, 19 & $1,2,3,4,5$ & \\
\hline \multirow{9}{*}{$\begin{array}{l}\text { Varlık Vergisi } \\
\text { Etkinlik Ör- } \\
\text { neği }\end{array}$} & Kanit 1, 2 & $1,2,3$ & \multirow{9}{*}{1 saat 12 dakika } \\
\hline & Kanit 3 & $1,2,3$ & \\
\hline & Kanit 4 & $1,2,3,4$ & \\
\hline & Kanit 5, 6 & 1,2 & \\
\hline & Kanit 7,8 & $1,2,3$ & \\
\hline & Kanit 9, 10, 11 & $1,2,3$ & \\
\hline & Kanit 12, 13 & $1,2,3$ & \\
\hline & Kanit $14,15,16$ & $1,2,3$ & \\
\hline & Kanıt 17, 18, 19 & $1,2,3$ & \\
\hline \multirow{16}{*}{$\begin{array}{l}\text { Haçlı Sefer- } \\
\text { leri Etkinlik } \\
\text { Örneği }\end{array}$} & Kanıt 1, 2 & $1,2,3$ & \multirow{16}{*}{1 saat 10 dakika } \\
\hline & Kanit 3, 4, 5 & $1,2,3,4,5$ & \\
\hline & Kanit $6,7,8$ & $1,2,3,4$ & \\
\hline & Kanıt 9, 10 & $1,2,3$ & \\
\hline & Kanit 11 & $1,2,3,4$ & \\
\hline & Kanit 12,13 & 1,2 & \\
\hline & Kanıt 14 & 1,2 & \\
\hline & Kanit $15,16,17$ & $1,2,3,4,5$ & \\
\hline & Kanit 18, 19, 20 & $1,2,3$ & \\
\hline & Kanit 21, 22 & $1,2,3,4$ & \\
\hline & Kanit 23 & $1,2,3,4,5$ & \\
\hline & Kanit 24 & 1,2 & \\
\hline & Kanit 25, 26 & $1,2,3$ & \\
\hline & Kanit 27, 28 & $1,2,3,4,5,6$ & \\
\hline & Kanit 29 & 1 & \\
\hline & Kanit 30, 31 & $1,2,3$ & \\
\hline
\end{tabular}




\section{Verilerin Çözümlenmesi}

Kayda geçirilen ifadeler ve notlar yazıya aktarıldıktan sonra metin kendi içerisinde değerlendirilmiştir. Bu değerlendirme sürecinde olabildiğince tarafsız olunması gerekmektedir. Araştırma verilerinin olabildiğince objektif yapılabilmesi amacıyla içerik analizi yöntemine başvurulmuştur (Yıldırım ve Şimşek, 2013; Patton, 2014). Bunun yanı sıra gözlem sonucunda elde edilen notlar ve kayıtlar çözümlenerek analiz edilmiştir. İçerik analizi bağlamında yapılan 3 etkinlikte elde edilen verilerin benzerlik ve değişkenlik dinamikleri göz önünde bulundurularak tasnif edilmiştir. Bu tasnif neticesinde oluşturulan temalar çevresinde veriler düzenlenerek analiz edilmiştir. Bu temalar etkinliklere ilişkin başlıkların içerisinde tartışılmıştır. Böylelikle elde edilen karışık veriler düzenlenerek okumaya hazır hale getirilmiştir.

\section{Bulgular}

\section{1. “Kardeş Katli”' Konulu Etkinlik Örneği}

30 Aralık 2018 tarihinde yapılan Kardeş katli konulu uygulamada Kanıt 1'de bulunan Fatih'in yayınladığ 1 ve kardeş katlini meşrulaştıran ferman üzerine tartışan çocuklardan Ö8 okudukları metinde kardeşlerin "devletin bekası için" katledildiklerini söylemektedir. Ö6'da “ülkenin düzeni için” yapıldığını söylemektedir. Ö6 ve Ö8 Osmanlıların uygulamasını daha çok kanun ve düzen eğiliminde gerçekleştirdiklerini ifade etmektedirler. Ö9 bunun "kardeşler arasında ego yarışlarından" kaynaklandığını söylemektedir. Ö9, Osmanlıların kardeş katlini saf çıkarcı eğilime uygun olarak gerçekleştirdiğini ifade etmektedir. Ö7 konuyla ilgili araya din adamlarının sokularak halkın kardeş katline karşı sessiz kalınmasının sağlanmak istendiğini söylemiştir. Olayın din adamlarıyla meşrulaştığını ve din adamlarının da üzerinde yer alan padişahların dini ve din adamlarını kullandıklarını söylemiştir. Ö7 kardeş katlinin "ekser ulema dahi tecviz etmiştir" ibaresinin kanun ve düzen düzeyine uygun olduğunu ifade etmektedir. Bu tartışma üzerine Ö8 söz hakk1 alıp "dinin insanları birleştiren bir şey” olduğunu ifade ederek Ö7’ye karşı çıkmıştır. Öğretmen dinin kardeş katli için meşrulaş̧ırıcı bir sebep olup olmadığını sorunca pek çok öğrenci evet diyerek yanitlamıştır.

Ö3, Kanıt 2'deki olayı kardeş katli normunun dışında olmasına rağmen olumlu olarak nitelendirmektedir. Benzer biçimde Ö8 de "adaletsiz [toprak] pay- 
laşılmasına engel oluyor" ve Ö4 önceden paylaşılarak aslında karışıklıkları engelliyor diyerek Selçukluların bu uygulamalarını sosyal sözleşme düzeyinde değerlendirmişlerdir. Ö2 bu fikirlere katılmayarak yine sorunların devam edeceğini söylemektedir. Ö2, Kanıt 2'de verilen örneğe kanun ve düzen eğiliminde yaklaşmaktadır. Ö2'nin bu ifadelerinden sonra Ö7, Kanıt 2'deki durumun ülkenin parçalanmasına neden olabileceğini söylemiştir. Ö7 Selçukluların Kanıt 2'de verilen uygulamalarına kanun ve düzen eğiliminde yaklaşmaktadır. Ö8 bu tartışmadan sonra bir önceki fikrinde ve ahlaki yargısında değiştirip "herkesin aldığ kendisine ait olmalı" diyerek kanun ve düzen eğilimine yönelmektedir. Bir önceki ifadesinde bu dağıtımın daha adil olabileceğinden söz etmiştir. Şimdiyse kardeş katlindeki gibi güce dayalı bir anlayışa yönelmektedir. Ö9, konu hakkında "başta anlaşabilir ama sonra bir açgözlü çıkar der ki neden kardeşlerimde bir tane fazla var bende de olsun" ifadelerini kullanmıştır. Ö9, Kanıt 2'de verilen olaya saf çıkarcı bir perspektiften yaklaşmaktadır. Tuğrul ve Çağrı Beylerin yapmış oldukları antlaşmadan sonra herhangi bir sorunla karşılaşıp karş1laşmayacakları sorulduğunda Ö3 karşılaşmayacaklarını söylerken Ö4, Ö5 ve Ö7 aralarında görüş ayrılıklarının doğabileceğini söylemişlerdir. Bu bağlamda Ö3 Selçuklu Sultanlarının sosyal sözleşme evresine uygun olarak hareket edeceklerini ifade ederken Ö4, Ö5 ve Ö7 Selçuklu Sultanlarının saf çıkarcı olarak hareket edebileceklerini ifade etmişlerdir. Ö3 görüşünde 1srar ederken Ö10, Selçuklu Sultanlarının birbirleri arkasından iş çevirebileceklerini ifade ederek onların saf çıkarcı olarak hareket edebileceğini söylemiştir.

Kanit 4'te Mu-
hammet Tapar ve Beryaruk arasindaki mücadele için Ö7 "Hocam ikisi de bu Fatih'in yaptığı gibi nizam- $\iota$ âlem için kardeşini katletmeye çalışmış. Çünkü devleti kendisinin daha iyi yöneteceğini düşü-

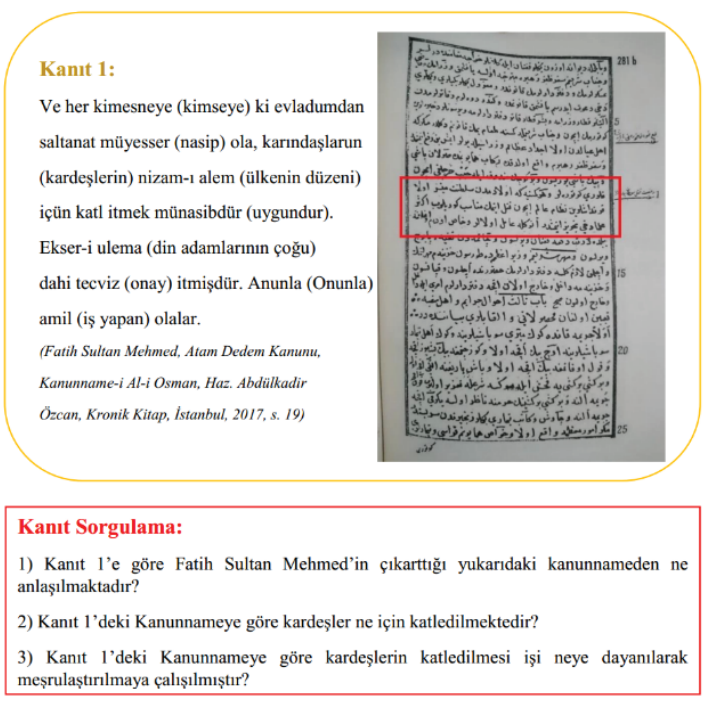

Şekil 1: Kardeş Katli Etkinlik Örneği 
nüyordu. Aslında sadece bireyci değil devletçi bir anlayış var. İkisi de devleti kendisinin daha iyi yöneteceğini düşünüyor. Sadece bireyci bakmamak lazım" ifadelerini kullanmıştır. Ö7 sosyal sözleşme evresine uygun yanıt vermiştir. Ö9, Muhammet Tapar'ın tahta geçtikten sonra kardeşi Berkyaruk'a isyan ettiğini ve kardeşini mağlup ettiğini ifade ederek bunun cüretsizlik olduğunu söylemiştir. Bu kardeş katlinin ve veraseti öne çıkaran bir anlayış olup kanun ve düzen eğilimine yakındır. Öğretmen Berkyaruk ile Muhammet Tapar'ın mücadelesinde âlimlerin devreye girmesini Fatih kanunnamesindeki ulemanın onayı doğrultusunda değerlendirmelerini istemiştir. Ö8, Selçuklu ulemasının barışı, Osmanlı ulemasınınsa katli onayladıklarını ve bunun çeliştiğini söylemiştir. Ö6 ise "din adamlarının ortalığl sakinleştirmeye çalıştıklarını" ifade etmiştir. Ö7 ve Ö3, padişahın ulemaya adamlarına talimat verdiği için onların bunu söylemeye mecbur kaldığını söylemişlerdir. Genel olarak öğrenciler Kanıt 4'teki din adamlarını ceza ve itaat döneminde görmektedirler. Ö7 ise ulemanın Fatih kanunnamesiyle padişah etkisinde kaldığını ancak Berkyaruk ve Muhammet Tapar arasındaki olayda kendi inisiyatiflerini kullanabildiklerini söylemiştir. Ö7, sadece Fatih Kanunnamesindeki ulemayı ceza ve itaat döneminde değerlendirirken Selçuklu dönemi din adamlarını sosyal sözleşme evresinde değerlendirmiştir. Öğrenciler kardeşler arası mücadeleyi dış ilişkiler açısından sakıncalı olarak betimlemişlerdir. Kanıt 4'ü aile bağları açısından değerlendiren öğrencilerden Ö7 küçük yaştaki şehzadelerin başa geçeceği bilindiğinden çevresinde onu kullanmak isteyen pek çok kimsenin bulunabileceğine işaret etmiştir. Ö6 da benzer ifadeler kullanır. Öğretmenin sorusu üzerine Ö8, Ö6 ve Ö7 ile beraber bunu dalkavukluk olarak değerlendirir. Şehzadelerin çevresindekilerce araçsallaştırılabilmesi durumu kişiler arası uyum dönemine uygundur.

Kanıt 5'e göreyse Ö3, Ö7, Ö8 küçüklügünü beraber geçiren

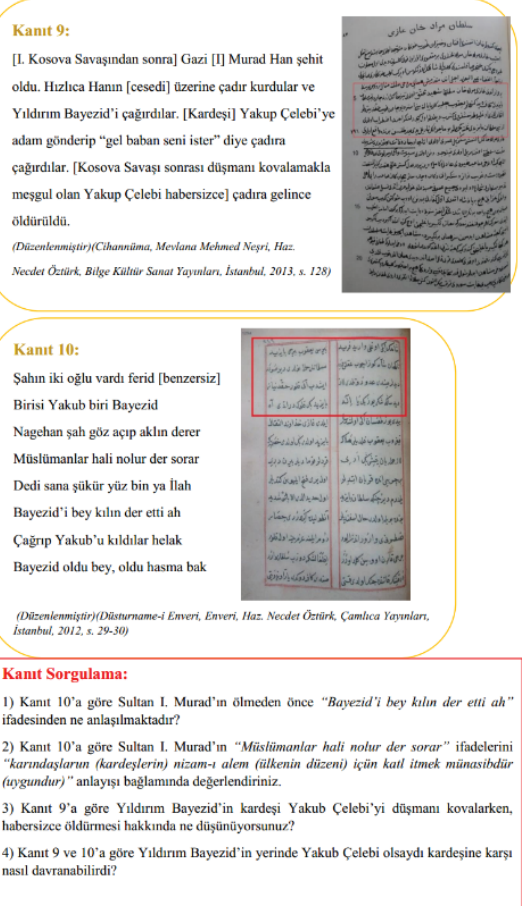

Şekil 2: Kardeş Katli Etkinlik Örneği 
kardeşlerin, kardeş katlinden sonra geçmişi hatırlayıp hüzünleneceklerini söylemişlerdir. Ancak Ö9 buna karş1 "Yine de bir şey fark etmez bence. Sonuçta zirve tek kişilik, zirveye oturduysa o yaşadiğı anıların pek bir önemi yoktur. Çünkü devlet onun yani artık istediğini yapacak” demiştir. Ö9 bu bağlamda kanun ve düzen eğilimi göstermektedir. Ö9 şehzadelerin tahtı devlet bekası için değil kendileri için istediğini söylemiştir. Bu nedenle Ö9'un ifadeleri saf çıkarc1 eğilimdedir. Ö2 şehzadelerin birbiriyle ilişkileri hakkında "Bunlar kardeş katlini bildikleri için birbirleriyle bu kadar çekişme içindeler. Barı̧̧salar bile tekrardan bozulur" diyerek şehzadelerin arasındaki ilişkileri saf çıkarcı şekilde değerlendirir. Ö7 "Başta tepki topluyor daha sonra insanlar alışlyor. Çocukken bile bunun farkında empoze edilmiş ona. Biliyor yani ileride ne olacağını" diyerek durumun normalleştirildiğini söylemiştir. Ö7'nin deyimiyle durumun şehzadelere empoze edilmesi ve onların bunu normalleştirip kabullenmeleri kanun ve düzen eğilimiyle örtüşmektedir.

Kanıt 6 ve 7'yi okuyan öğrencilerden Ö3, Osman Gazi'nin amcası Dündar'1 öldürmesini "Ben padişahım senin benim kararıma karışma hakkın var mı?" ifadeleriyle desteklemiştir. Bu durum Ö3'ün kanun ve düzen eğiliminde bir ahlaki yargıyla olaya yaklaştı̆̆ını görülmektedir. Ö9, Osman Gazi’nin yanında böyle düşünen birisini istememesini anlaşılır bulduğunu söyleyerek kanun ve düzen eğiliminde gözükür ama daha sonra Dündar Bey'in öldürülmesi olay1nın tartış1ır olduğunu söyleyerek tartışmanın ucunu açık bırakır. Ö2, Dündar Bey'in tek sözle öldürülmesinin yanlış olduğunu söylemiştir. Ö9 bunu diyen bir kimsenin ileride Osman Gazi’ye düşmanlık edebileceğini, Ö3 “yılanın başını küçükken ezeceksin" söyleyerek konuya kanun ve düzen eğiliminden yaklaşmışlardır. Ö2 ve Ö4, Dündar'ın eleştirilerini haklı bulurken Ö9, Dündar'ın eleştirilerini menfaat elde etmek için olduğunu düşünmekte ve onu saf çıkarcı biçimde yorumlamaktadır. Öğrencilerin çoğu Kanıt 7'de Alaaddin Paşa'nın tahtı anlaşarak Orhan Gazi’ye bırakmasını olumlu karşılaşmışlardır. Bu sosyal sözleşme düzeyinde değerlendirilebilir. Osman Gazi'nin amcası Dündar'ı devlete tehdit olarak görüp görmediğiyle ilgili soruya Ö7 ve Ö8 olumlu cevap vererek Osman Gazi'nin kanun ve düzen eğiliminde hareket ettiğini söylemişlerdir.

Kanıt 8'de ufak şehzadelerin nizam-1 âlem için tehdit oluşturup oluşturmadığına ilişkin soruya Ö3 çocuklarken hayır cevabını vermiştir. Kanıt 9'u okuyan öğrenciler I. Murat'ın "Yıldırım'ı benden sonra bey kılın” cümlesini yorumlarlar. Ö4 kaynağı sorgulayarak bunun Yıldırım'ın tahta çıkışının meşrulaştırılmak için yazıldığını ifade etmiştir. Ö7, olayın dramatikleştirilmek için yazılmış 
olabileceğini söylemiştir. Ö4 ve Ö7, devrin tarihçisi olan Enveri'nin bakış açısını saf çıkarcı olarak yorumlamışlardır. Ö3, Enveri'nin aktardıklarının doğru olarak yorumlamış ve bunu I. Murat'in taht kavgalar1n1 engellemek için yaptığını söylemiştir. Ö3 bu olay için Osmanlıların, kanun ve düzen eğiliminde düşündüklerine işaret etmektedir. Öğretmenin Yildırım'in kardeşi Yakup Çelebi'yi öldürmesinin nizam-1 âlem açısından doğru olup

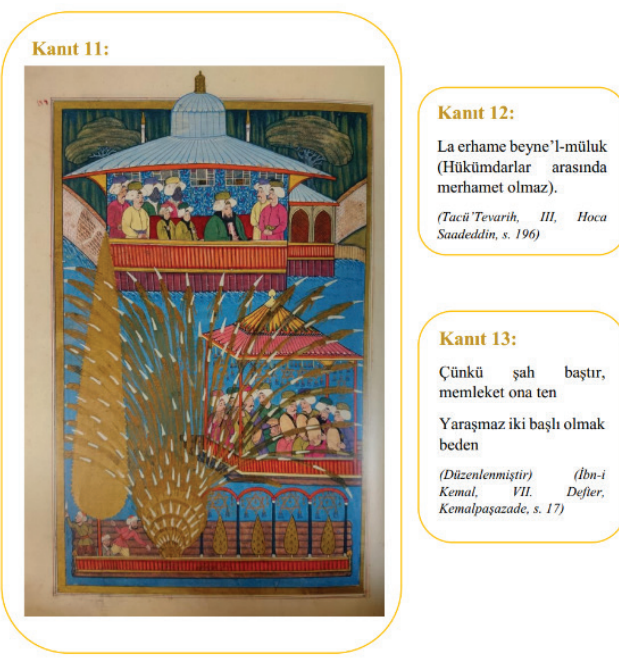
olmadığı sorusuna Ö9

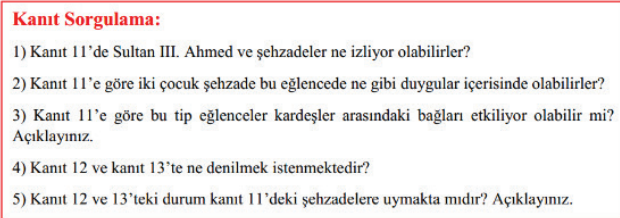

5) Kanıt 12 ve 13 'teki durum kantt 11 'deki şehzadelere uymakta mıdır? Açıklayınız.

Şekil 3: Kardeş Katli Etkinlik Örneği

"Yani nizam-l âlem için, ülkenin düzeni için doğru bir anlayış bu söylenilenlere göre" demiş ve kanun ve düzen eğilimine uygun cevap vermiştir. Öğrencilerin burada kardeş katlinden çok Yıldırım'ın katletme şekline karşı bir hassasiyet geliştirdikleri görülmektedir. Yıldırım'ın kardeşi Yakup Çelebi'yi öldürmesinden ziyade öldürme şekli pek çok öğrenci açısından olumsuz bulundu. Ö4 bunu alçakça, Ö3 çok yanlış, Ö8 alçakça, Ö2 güç savaşı olarak yorumlamıştır. Öğrenciler kardeş katli kapsamında olsa da bunun yapılış tarzı nedeniyle Yıldırım'ın hareketini saf çıkarcı eğilimde değerlendirmişlerdir. Zira Ö4 Yıldırım düşmanı kovalasa ve Yakup Çelebi babasının na'şını görseydi durum nasıl olurdu sorusunu yöneltmiştir. Ö3 mağdur olarak gördüğü Yakup Çelebi için "bence yapmazdl" diyerek yanıt vermiştir. Buna karşı Ö4 "tanımadığımız birisi”" diyerek Yakup Çelebi’nin ne yapacağının kestirilemeyeceğini Ö7 babasının ölmüş olduğunu o sebeple Yıldırım'ın da geri döneceğini söylemiştir. Ö2, Yakup Çelebi'nin kardeşini öldürmek amacıyla olmasa da davet edeceğini ama daha sonra belki öldürebileceğini Ö7 belki hemen değil ama daha sonra öldürebileceğini ifade etmiştir. Ö2 ve Ö7, Yakup Çelebi’nin kanun ve düzen eğiliminde hareket edeceğini varsayarken onun mağdur sıfatıyla kardeş katlini daha "dü- 
rüstçe” gerçekleştireceğini söylemişlerdir. Öğretmen nihai olarak Yıldırım'ın yaptığının doğru olup olmadığını sorduğunda Ö3 çok yanlış bulmuş, Ö4 babası öldüğü için Yıldırım'ın mecbur kaldığını bu sebeple öldürdügünü söylemiştir. Ö6 ve Ö10, Ö4'ün görüşlerini mantıklı bulmuştur. Ö7, Yıldırım'ın bu kararı ani almadığını ve önceden beri aklında var olan düşünceyi firsatı bulunca hayata geçirdiğini söylemiştir. Bu bağlamda Ö4, Ö6, Ö7 ve Ö10, kanun ve düzen eğiliminde hareket etmektedirler. Ö9, eğer Enveri’nin aktardığı doğruysa ve I. Murat tahtı oğlu Yıldırım'a verdiyse katlin doğru olduğunu söyleyerek kanun ve düzen eğilimde ancak eğer Enveri'nin aktardığı yanlışsa Yıldırım'ın “kalleşlik" yaptığını söyleyerek Yıldırım'ın saf çıkarcı biçimde hareket ettiğini ifade etmiştir. Ö8, Yıldırım'a “saltanat gözünü karatmış” diyerek saf çıkarcı biçimde hareket ettiğini ifade etmiştir. Kanun ve düzen eğilimi baskın olsa da Yakup'un öldürülme tarzı öğrenciler arasında ciddi tartışma konusu olmuş ve Ö7 ne olursa olsun Yıldırım'ın bu olay için babasını kullanmasının yanlış olduğunu söyleyerek sosyal sözleşme eğiliminde yargı geliştirmiştir. Ö9'un yukarıda zikrettiği ve Enveri'de aktarılan babanın yani I. Murat'ın oğlunu veliaht tayin etme durumu öğrenciler arasında kanun ve düzenin belki de en eleştirilmez durumlarından birisi olarak temayüz etmiştir. Bu yargının öğrencilerin güncel yaşamları, babanın aile içindeki durumu ve ataerkil, pederşahi toplum yapısıyla da yakından ilişkisi olduğu düşünülebilir. Zira tartışmanın sonlarına doğru Ö3 "şimdi dediği gibi öyle bir şey yazdlysa babası kardeşi de buna uymak zorunda değil mi?" Ö7 ise "Onu yazan babası mı hocam?" sorularını sorarak babanın tartışılmaz, meşru otoritesine vurgu yapıp kanun ve düzen eğilimine yönelmişlerdir. Ö5, Yıldırım'ın kendisine güvenemediği için kardeşini öldürdüğünü ve bunun yan1ış olduğunu dile getirmiştir. Bu görüsse katılan Ö9 "Kendisine güvenmiyordu o zaman kardeşi ondan daha iyiydi" diyerek yorumlamıştır.

Kanıt 11'i inceleyen öğrenciler şehzadelerin birbirlerine karşı ne hissettiklerini anlamaya çalışmışlardır. Bu bağlamda Ö6 "Bence şöyle bir şey kendi ölümünü düşündüğü gibi kardeşinin de ölümünü düşünüyor. Daha da çelişkiye düşebilir. Ölümün kötü bir şey olduğunu hissederse kardeşine klyamayabilir" demiştir. Ona cevaben Ö7 "Öldürmese kendisi ölecek" diyerek şehzadelerin düştüğü ahlaki ikilemi tasvir etmiştir. Öğrenciler Kanı 14'ü okumuş ve Ö10 fetret devri gibi dönemlerde büyük karışıklıkların yaşandığını ancak kardeş katli dönemlerinde devletin daha düzenli ilerlediğini söyleyerek kanun ve düzen eğilimine yönelik bir çıkarım yapmıştır.

Bundan sonra kanıt 15, öğrenciler tarafından incelenmiş ve öğretmen tarafından "Fatih'in tahtı Cem'e birakmasindan sonra Bayezid'in kanuna göre yani 
Fatih'in koyduğu kanuna göre tahta çıkmasını nasıl değerlendiriyorsunuz?" sorusu yöneltilmiştir. Ö7 bu bağlamda Fatih'in kendisiyle çeliştiğini söylemiş ve hem kardeş katlini yasallaştırıp hem de tahtta istediği oğlunu görmek istediğini söylemiştir. Ö7, Fatih'in bu hareketini saf çıkarcı olarak değerlendirmekte ve kanun ve düzen eğilimine tamamen ters bulmaktadır. Ö4 ise Fatih'in kardeş katli olabileceğini ifade ettiğini söyleyerek, Fatih'in aslında kanun düzen eğilimine uygun olarak hareket ettiğini söylemiştir. Öğretmenin, II. Bayezid'in kardeşi Cem'i öldürdükten sonra na'şını getirterek onun için hayırlar yapmasını samimi buluyor musunuz? sorusunu Ö6 "göz boyamak için" şeklinde yanıtlayarak II. Bayezid'in bu olayda kişiler arası uyum evresinde bir yargıyla hareket ettiğini ifade etmiştir. Ö7 kaynağın doğruluğunu sorgulayarak onun meşrulaştırmaya yönelik olabileceğini söylemiştir. Kaynağın saf çıkarcı davranabileceğini ifade etmiştir.

Öğrenciler Kanıt 17'yi okuduktan sonra Ö4 “artık öyle bir duruma gelmişler ki herkesin gözünde taht varmış gibi öyle algllyyorlar. Iyi niyete kapalıymış gibiler" yorumunda bulunmuştur. Bu Ö4'ün Osmanlı padişahlarının kardeş katlindeki tutumunu saf çıkarıcı anlayışla yaptıklarını düşünmeye başladığını göstermektedir. Korkut'un Yavuz'a yazdığı mektubun samimi olup olmadığıyla ilgili sorudaysa Ö8 mektubu samimi bulduğunu ifade etmiştir. Ö6, samimi bulmamaktadır. Ö7 ise Korkut'un tamamen kişiler arası uyuma uygun olarak hareket ettiğini ve hayatını kurtarmak için Yavuz ile iyi geçinmeye çalıştığını ifade etmiştir.

Konunun bitiminde öğretmenin kardeş katli gerekli midir? sorusuna Ö3 "Bence çok saçma ve gereksiz bir şey" diyerek cevap vermiştir. Aslında çoğu yerde kanun ve düzen eğiliminde davranan Ö3'ün Yıldırım ve II. Bayezid'in kardeşlerini nasıl katlettiğini öğrendiğinde verdiği tepkilerin onun nihai kararı üzerinde böyle bir etki yapmış olabileceğini göstermektedir. Ö6 ise dönemin şartlarını ön plana çıkararak "Kötü bir şey ama o zaman için gerekli" diyerek durumu sorgular biçimde olsa da kanun ve düzen eğiliminde hareket etmektedir. Ö9 gerekli olmadığını söylemiştir. Ö7 "Zaten hocam buna iki açıdan bakabiliriz vicdani açıdan tamamen yanlış ama pratik açıdan bakarsak tamamen doğru” diyerek konuya dair ahlaki ikilemin kökenini gözler önüne sermiştir. Ö8 "bence kardeş katli mantıkl bir şey ama padişahların psikolojisini bozuyor" diyerek kanun ve düzen eğiliminde hareket etmiş ancak ortaya çekincesini de koymuştur. 


\section{2. "Varlık Vergisi" Konulu Etkinlik Örneği}

11 Ocak 2019'da yapılan Varlık vergisi uygulamasında Kanıt 1 ve 2'de savaş zamanı Türkiye'nin ekonomik durumu hakkında verilen tabloyu öğrenciler yorumlamışlardır. Kanıt 3'e gelindiğindeyse ekonomik şartlarla düşünülmek şartıyla halkın vergi vermesinin doğru olup olmadığ1 sorusu öğretmen tarafından öğrencilere yöneltilmiştir. Ö7 bunu normal karşılarken Ö9 olmaması gerektiğini ifade etmiştir. Ö6, savaş şartlarından ötürü zaten hayat pahalılığının olduğunu ve vergi verilmesinin halk içerisinde huzursuzluğa yol açabileceğini ifade etmiştir. Öğrencilerin burada devlet ve halk olarak iki farklı perspektiften baktığ 1 görülmektedir. Bu duruma karşı Ö7 "peki o zaman vergi alınmasa ne olacak" sorusunu yöneltir. Ardından Ö2 ve Ö8 savaş durumunu hatırlatarak şu anla k1yaslanamayacağını söylemişlerdir. Ö1, durumun kültürden kültüre değişeceğini kendisininse böyle bir durumda fedakârlık yapabileceğini ifade etmiştir. Ö9'un görüşü dışında öğrencilerin vergi toplaması konusunda genel olarak kanun ve düzen eğiliminde oldukları gözlemlenmektedir. Ö9, itirazlarını sürdürerek vergiyi vermeyen insanların da çıkabileceğini ve toplumun ikiye bölünebileceğini söylemiştir. Bu bağlamda sayıca hayli fazla olan karşıt grubu itirazları karşısında tavrını biraz daha yumuşatarak toplumun ayrışabileceği iddiasını öne sürmüştür. Ö7, insanların maddi durumlarına göre vergilendirme yapılabileceğini ifade ederek ara bir çözüm yolu aramaktadır. Bu bağlamda Ö7'nin konunun bu noktasına yaklaşımı sosyal sözleşme eğilimindedir. Öğretmenin bu durumun halk içerisinde ayrışmaya neden olup olmayacağ1 sorusuna Ö7 "Birisi ekmek bulamıyor. Eşitlikle adalet aynı şeyler değil” cevabını vermiştir. Ö7 bu konuda sosyal sözleşme eğiliminde bir kanıya varmaktadır. Ö8 ise vergilerin nereye gittiğinin vergi verip vermeme noktasında önemli olduğunu söylemiştir. $\mathrm{Bu}$ bağlamda verginin anlamını sorgulayan Ö8 sosyal sözleşme düzeyinde bir ahlaki eğilime yakındır. Türkiye'de Varlık vergisi uygulamasının sosyoekonomik şartlarından dolayı alındığını ifade eden Ö7 dünyada örneğin İngiltere'de iktisadi yapının nasıl olduğuna ilişkin bir kanıt göremediğini bu sebeple bunu yanıtlamanın zor olacağını ifade etmiştir. Öğretmenin İngiltere'nin iktisadi durumunun savaş dolayısıyla pek iyi olmadığını ifade etmesi üzerine Ö7 Varlık vergisini normal karşılayabileceğini ifade etmiştir.

Öğretmenin Varlık vergisini adil buluyor musunuz? sorusuna Ö7 bence normal diyerek cevaplamış Ö9, halkın geri kalanında da alınsın bence normal değil cevabını vermiştir. Bu sözünden bir zaman sonra Ö9 "bizde para yoktu biz verdik" diyerek saf çıkarcı biçimde hareket etmektedir. Ö6 ise "Adil değil ama 
normal bir şey" olarak değerlendirmiş ve bu düşüncelerini o dönem için yapılacak bir şey yoktu şeklinde izah etmiştir. Ö2 "şöyle bir durum var o adam çalışıp da oraya gelmiş. O parayı kendi çabasıyla yapmış" demektedir. Bireysel çıkarı ön plana alan bu tutum saf çıkarcı bir değerlendirme olarak nitelendirilebilir. Ö7 herkes için daha adil bir çözüm üretmeye çalışır ve alınan vergilerin ülkenin ekonomisi düzeldikten sonra sahiplerine tek-

\section{KANIT 4:}

Birçok ülkede ise servet vergisi niteliğinde ve 0 adı taşıyan ölçüde vergiler tarh edildi [salındi]. Yunanistan, Bulgaristan ve İsviçre'de "geçici" nitelikte olmak üzere bu tür vergiler uygulandı. [...] Amerika Birleşik Devletleri'nde şirketlerin kazançları \%94 oranında vergilendi. $\mathrm{Bu}$ vergiye Wealth Tax (Varlık Vergisi) adı verilmiștir. Almanya'da Olağanüstü Savaş Kazançları Vergisi ise daha önceki yılların vergilerinin $\% 150$ 'si oranında bir vergi idi. Ayrıca alınan ek vergi ile birlikte bunlar toplam kazançların \%85'inin vergi olarak alınması sonucunu vermekteydi. Savaş uzayıp giderken bu önlemler günden güne arttırılmıștı. İngiltere'de olağanüstü kazançların (Exess Profit Tax) oranı \%100 olmuş yani kurumların kazancı tamamıyla vergi olarak Hazine'ye alınmıştır. İsviçre'de yeni tüketim vergileri yanında "Tek Vergi" adı altında bir servet vergisi alınması yoluna gidilmiștir. Vergi üç yılda ve taksitler halinde alınmıştır. Fransa'da kazanç ve gelir vergilerinin oranları yükselmiştir. Bu büyük ekonomiler dıșında kalan Yunanistan'da geçici bir servet vergisi uygulanmıștır. Bulgaristan'da Yahudilerden ayrı bir vergi alınması düşünülmüştür. Macaristan'da da bir defada alınacak bir servet vergisi kabul edilmiștir.

(Savaș Türkiye Varlk Vergisi, Cahit Kayra, Tarihçi Kitabevi, Istanbul, 2011, s. 36-37)

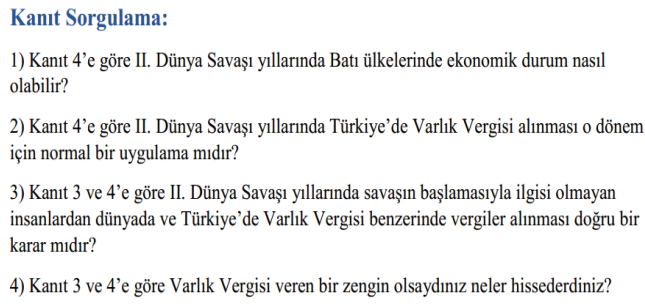

2) Kanıt 4'e göre II. Dünya Savaşı yıllarında Türkiye'de Varlık Vergisi alınması o dönem için normal bir uygulama mıdır?

3) Kanıt 3 ve 4'e göre II. Dünya Savaşı yıllarında savaşın başlamasıyla ilgisi olmayan insanlardan dünyada ve Türkiye'de Varlık Vergisi benzerinde vergiler alınması doğru bir karar midir?

4) Kanıt 3 ve 4'e göre Varlık Vergisi veren bir zengin olsaydınız neler hissederdiniz? rar iade edilmesinin bir çözüm olabileceğini söyler. Bu çözüm önerisi ve tarafların düşünülmesi sosyal sözleşme ilkesiyle uyumlu olarak değerlendirilebilir. Buna karşı Ö9 ve Ö6 böyle bir sözün verilemeyeceğini ve tutulamayacağını ifade etmişlerdir. Ö9 kendi kazandığı parayı vergi olarak vermeyi yanlış bulduğunu ifade ederek saf çıkarc1 bir eğilim sergilerken Ö2 uygulamanın adil olmadığını dile getirmiştir. Ö7 "Eşitlik yok ama adalet var. Fakirden alsalar en fazla ne alabilecekler ki?" diyerek uygulamayı desteklemiştir.

Kanıt 5 ve 6 öğrencilere gösterilip Varlık vergisinin muhalifleri özellikle gayrimüslimleri sindirmek için bir araç olarak kullanılıp kullanılmadığına ilişkin soruya Ö5 "firsata çevirmiş olabilirler" cevabını vererek o dönemde insanların saf çıkarcı bir yargıyla hareket ettiğini ifade etmiştir. Ö8 iktisadi tabloları ima ederek ekonomik durumun kötü olduğunu söylemiştir. Ö1, direk kaynağı sorgulayarak kanıt bulunan yazıyı yazan kişinin muhalif olabileceğini söylemiştir. Ö1 olayın firsata çevrildiğini söyleyerek saf çıkarcı bir biçimde hareket edildiğini ima etmiştir. Ö7 de benzer bir biçimde cevap vermiştir. Öğretmen Kanıt 7'de Varlık vergisini vermediği için Aşkale'ye çalışma kampına gönderilen bir va- 
tandaşla ilgili metni gösterince Ö9 "kendi parası hakll" şeklinde yanit vermiştir. $\mathrm{Bu}$ bağlamda saf çıkarcı bir yargıla hareket ettiği söylenebilir. Kanıt 7 gösterildikten sonra vergi mükelleflerinin memurlara ve devlete karşı nasıl bir hissiyat içerisinde olabileceği sorulduğu zaman Ö9 kin beslediklerini ifade eder. Ö3, "Kin besliyorlardir da hocam onların görevi sonuçta" demektedir. Ö3'ün bu yargısı kanun ve düzen eğiliminde denilebilir. Ö3 para vermeyen kişi-



Mektuplarda üzüntüden saçlarının beyazladığını yazmıs olacak ki: Leon eșini eğlendirmek için şöyle yazmış fotoğrafin arkasına: "Açık havada çektirdiğim bu fotoğrafta da görebileceğin gibi birkaç tüy dışında saçımda beyaz yok. Saçlarım halen kahverengi. Anlayacağın, havamdan hiçbir şey kaybetmedim... Uçup giden gençliğimden bana kalan tek iz de bu zaten..."

(Varlik Vergisi, Hatralar-Tamklar, Rifat N. Bah, Libra Kitapşilh, Istanbul, 2012)

Şekil 5: Varlık Vergisi Etkinlik Örneği lerin o kadar çalıştım neden para vereyim şeklinde düşündüklerini ifade etmiştir. Ö3'ün Varlık vergisini ödemeyenlerin saf çıkarcı bir yapıda düşündükleri fikrinde olduğu gözlemlenmektedir. Öğretmenin zengin insanların vergi vermeyi istememesini nasıl değerlendiriyorsunuz? sorusu üzerine Ö9 "Işste hocam zenginler mi batırdı ülkeyi? Niye onlar ödemek zorunda" demiştir. Bunun üzerine Ö7 "Onlardan alınıyor çünkü onlarda artı var" demiştir. Ö9 ise "vermek istemiyor" demiş buna karş1 Ö7 "Bireyi düşünürsem tabi ki istemem ama toplumu düşünürsek benim param topluma yarayacağını düşünüyorsa tabi ki verir" cevabını vermiştir. Öğretmen bunun üzerine bireyci mi yoksa toplumcu mu düşünmek doğru sorusunu sorduğu zaman Ö7 devrin şartlarını da göz önüne alarak "Bu devirde toplumcu" cevabını vermiştir. Ö6, bu konu hakkında toplumsalcı bir görüş öne sürerek "Bir şey diyeceğim şimdi ben vermedim diyelim, hani ülke battı. Bu sefer benim zenginliğim neye yarayacak ki? " sorusunu sormuştur. Ö1, bireyci düşünmemiz gerekiyor cevabını vermiştir. Ö2 de toplumsalc1 yorum yaparak "Şimdi şöyle bir şey var. Hocam vermese o zaman yiyecek kuyrukları da varmıs dışarı çıkamayacaksa o zaman çok zor bir yaşam olacak. O yüzden hepsinin vermesi 
lazım" ifadelerini kullanmıştır. Burada açıkça Ö2'nin tartışmanın başında sarf ettiği fikirlerinin değiştiği görülmektedir.

Ö3 Varlık vergisine dönüş yaparak "Ben vermezdim kampa da gitmezdim hocam. Hocam beni her almaya gelen memura rüşvet teklif ederdim" ifadeleriyle saf çıkarcı bir yargıda bulunmaktadır. Ö7 "Bir de Türklük bilinci yok adamda azınlı. Milletinden insanlar için harcanmayacak sonuçta bu para onun için" demiş ve ötekileşmeden söz etmiştir. Kimlik ve yarg1 arasındaki ilişkiye dikkat çekmiştir. Ö1 "Şimdi o zaman vereceği paranin kendi milletinden olmayan kişilere kullanmakla ailesini yani geride bıraktıklarını düşünmek var. Şimdi hangisini tercih edersin? Bence para verip başkaları için kullanılmasinı tercih etmek daha mantıklı. Yani hiç uğruna olsa bile verirsin" diyerek ikilemden söz etmiş ve aileden ayrılmamanın daha değerli olduğunu ifade etmiştir. Ö7 kendisine yöneltilen bu eleştiri üzerine bir önceki fikrini toplumumuzda önemli bir yeri olan

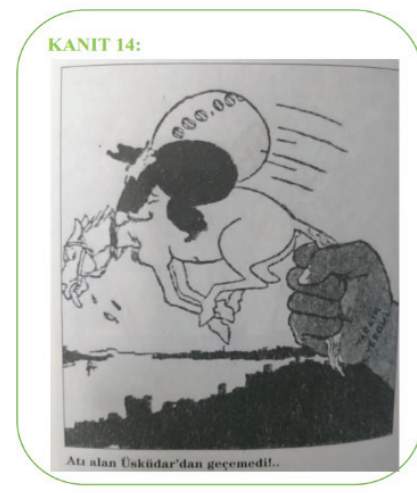
Kanit Sorgulama: 1) Kanit 14,15 ve $16^{\prime}$ ya göre Türk kamuoyu II Dünya savaşı yıllarında gayrimüslim vatandaşlan nasıl görmektedir? 2) Kanit 14,15 ve $16^{\prime} y_{1}$ kanit 13 เṣı̆ğında değerlendirin. 3) Kanit 14,15 ve $16^{\prime} y$ kanıt 12 ișığında de \$s̆ğınd

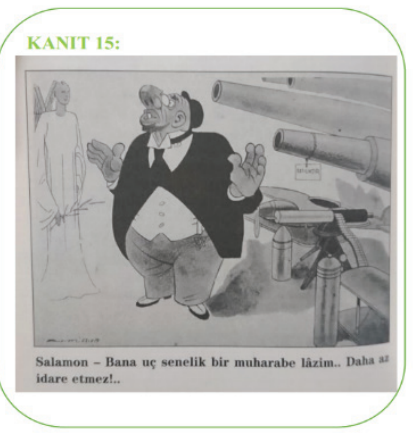

KANIT 16: Falih Rufkı Atay: Zeytinyağının fiyatııı bi hamlede 200 kuruşa firlatmışlar. Pirinci karaborsa fiyatmı iki misline çıkarmışlar. Sonra bu vurguncular, ellerine geçen bu milyonlardan şüph etmișler, büyük şehirlerde misli görülmemis bir sefahate, bir arsa alın satımına baslamısla Servetini birkac misl Serte temin snuf, vazife ve adale sınif, vazife ve adalet davasinda da ayrica imtiyazlı kalamaz.

(Savas Türkiye Varlık Vergisi Cahit Kayra, Tarihç Kitaben,

Şekil 6: Varlık Vergisi Etkinlik Örneği aile müessesesini de katarak yeniler ve "ama daha çok ailesini düşündüğ̈̈ için değil midir? Yani para bizde kalsin ailem daha zengin kalsın ben 1.5 y1l orada sürüneyim" ifadelerini kullanarak farklı bir yargı muhakemesi geliştirmiştir.

Pek çok yerde olduğu gibi burada da net olarak görülmektedir ki çocukların fikirlerinin zıt oluşu onların yeni çözüm yolları ve ahlaki yargılar oluşturmalarına imkân sunmaktadır. Bu birbiri üzerine gelişen ve farklı görüşlerin etkisiyle esneklik kazanan demokratik, katılımcı ve iş birlikçi bir süreç etrafında gelişmektedir.

Öğrenciler bundan sonra Kanıt 10 ve 11'i incelerler. Ardından Kanıt 12, 13, 14, 15 ve 16'yı incelerler. Burada Türk basınının gayrimüslimlere yönelttiği 
karaborsacılık yaptıkları iddiası hakkında öğrencilerle tartışılmış ve Türk basınındaki gayrimüslimlerin savaşı firsata çevirdiği görüşüne katılıp katılmadıkları sorulmuştur. Ö9 gayrimüslimlerin karaborsacılık yaptıklarını söyleyerek "Haklılar ben de olsam ben de aynısını yapardım " ifadelerini kullanmıştır. Ö9, saf çıkarcı bir ahlaki yargı ile olaya yaklaşmaktadır.

\section{3. "Haçlı Seferleri" Konulu Etkinlik Örneği}

24 Ocak 2019 tarihinde ise Haçlı seferleri ile ilgili üçüncü ve son uygulama yapılmıştır. Kanıt 1 ve 2 gösterildikten sonra İznik'in teslim edilmesi durumu öğrencilere sorulmuştur. Ö7, "ahlaki açıdan tamamen yanlış ama savaş stratejisi sonuçta" demiştir. Ö3 "böyle savaş stratejisi olmaz hocam. Insanlık bertaraf edilmiş" yorumunu yaparken Ö5 savaş stratejisi yorumuna karş1l1k "ters etki yapabilir, klşkırtıcı olabilir", ifadelerini kullanmıştır. Ö8 "Ahlaki açıdan yanlış ama yüzylllardır yapılan bir şey bu. Çünkü sadece Hiristiyanlar yapmiyordu. Timur da geldi, İzmir'i

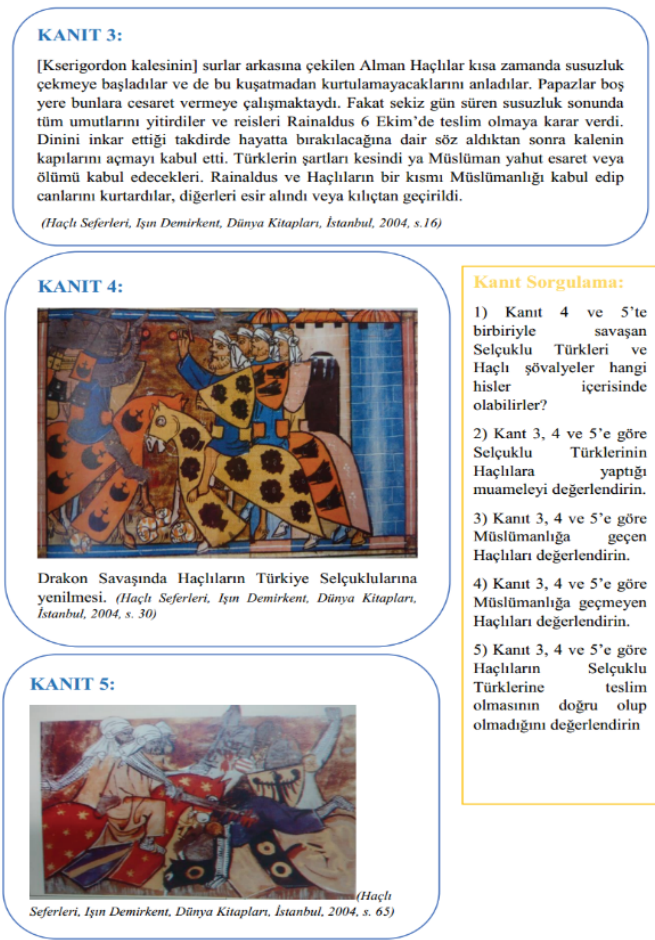

Şekil 7: Haçlı Seferleri Etkinlik Örneği kuşattıktan sonra öyle bir duvar yaptığl söyleniyor kafalardan. Bence savaş taktiğì” demiştir. Öğretmenin Selçukluların Haçlılara yaptığı muamele hakkında sorduğu soruya ilişkin ise Ö8, Ö3, Ö9 bunun bir cevap ve intikam niteliği taşıdığını ifade etmişlerdir. Ö7 ise savaşların ahlaki olmadığını ifade etmiştir. Kanıt 3, 4 ve 5 gösterildikten sonra öğrencilere İslam'1 kabul eden ve kabul etmeyip öldürülen Haçlıların H1ristiyanlar tarafindan nasıl değerlendirilmiş olabileceği sorulmuştur. Ö5 bunları korkak olarak nitelerken Ö9 faydacı davrandıklarından ötürü mantıklı bir hare- 
ket yaptıklarını ifade etmiştir. Ö8, öldürülenleri “salak” olarak nitelemektedir. Öğretmen aynı durum ile Müslümanlar karşılaşsaydı ne olurdu sorusuna Ö7 "biz davasına sadık olup ölenleri kesinlikle kahraman olarak nitelendirirdik" cevabını vermiştir. Ö3 böyle bir durumda din değiştirmeyi kabul etmezken mantıklı olanınsa din değiştirmek olduğunu söylemiştir. Ö9 ise din değiştirebileceğini söylemiştir.

Bundan sonra öğrenciler Kanıt 6, 7 ve 8'i incelerler. Kılıç Arslan'ın İznik'i bırakması üzerine kaledekilerin neler hissettiğinin sorulması üzerine Ö9 "İyi demiş, ben olsam öyle demezdim ama iyi demiş" demiştir. I. Kılıç Arslan'ın yapmış olduğu hareketi haklı ve mecbur kalınmış bir hareket olarak görmüş ve "denizden gemilerle gelmişler adamlar dayanmış kapıya ne yapacak?" ifadelerini kullanmıştır. Ö1, Kılıç Arslan'ın yanlış yaptığını düşünmektedir. Ö7 ise "objektif bakınca direk dışarıdan bakınca kendisi için iyi olanı yapmış. Ama o kişinin yerine koyduğunuzda tabi ki kötü” ifadelerini kullanarak ahlaki ikileme dikkat çekmiştir. Ö1, tarihten aldığı meşruiyetle "hainlik yapmış. Halid bin Ziyad gemileri yakmış yani" ve "İstanbul alınırken Bizans imparatoru tek başına çarpışıyordu" demiştir. Bu durum ahlaki muhakemede tarihin meşru bir alan olarak kullanıldığını açıkça göstermektedir. Bu tartışmalardan sonra öğretmenin Kılıç Arslan'ın İznik’ten çekilmesini nasıl değerlendiriyorsunuz? sorusuna öğrenciler farklı yanttlar vermişlerdir. Ö8 ve Ö5, I. Kılıç Arslan'ın taktiksel olarak hareket ettiğini beyan etmişlerdir. Ö8 bunu doğru bulduğunu ifade etmiş öğretmenin şehirdekileri kılıçtan geçirdiklerini söylemesi karşısında yapacak bir şeylerinin olmadığını ifade etmiştir. Ö8 ülkenin genelinin kurtarılmasının İznik şehrinin kurtarılmasından daha önemli ve stratejik bir adım olarak düşünmektedir. Ahlaki yargısı daha toplumsalcıdır. Ancak İznik şehrinde insanların başına gelenlere göz yumabilmiş ve bunları taktiksel bir mecburiyet olarak nitelemiştir. Ö1 ve Ö3, bunun yanlış olduğunu söylemiş ve Ö3 "bence yanllş̧ yapmış en azından onlara da bir taktik söyleyeydi. Ben kendimi kurtardım siz ne yapıyorsanız yapın içeride demiş" ifadelerini kullanmıştır. Ö3 burada Kılıç Arslan'ın taktiksel olmaktan ziyade İznik’tekileri yüz üstü bıraktığını ve saf çıkarcı biçimde hareket ettiğini ifade etmektedir. Bu görüşe karş1 Ö7, Ö8 ve Ö5'in görüşlerine benzer bir ifadeyle Ö3'ün görüşlerini eleştirerek “Aslında ben kendimi kurtardım değil de ben ülkeyi kurtarmaya çalışıyorum değil mi daha çok yani?" ifadelerinde bulunmuştur. Ö6 da Kılıç Arslan'ın hareketinin ihanet olarak değerlendirmiş ancak doğrusunun bu olduğunu ifade etmiştir.

Daha sonra Kanıt 9 ve 10’u incelenmiştir. Ö1 konuyla ilgili Türklerin daha 
insaflı davrandıklarını çünkü yanlış yapan Hıristiyanları cezalandırdığını söylemiştir. Ö4, Müslümanlarla ilgili verilen bilgileri sorgulayarak "ihanet ettiklerinden emin değiller ama asıyorlar" demiştir. Bu olayı Ö3 ve Ö8 ahlaki olarak değerlendirmemişlerdir. Öğretmen bu olayın savaş stratejisiyle alakalı olup olamayacağını sorması üzerine Ö3 olumsuz yanıt verirken Ö9 olabileceğini ve savaşta her şeyin mubah olduğunu söylemiştir. Bu durum saf çıkarcı eğilime yakındır. Ardından Kanıt 11 okunmuştur. Firuz'un yaptığı davranışı Haçlılar, Müslümanlar ve Firuz açısından değerlendiren öğrenciler son olarak kendi açılarından değerlendirmişlerdir. Böylece olaya farklı perspektiflerden bakabilmişler ve empati kurmaları kolaylaştırılmaya çalışılmıştır. Firuz'un yaptığı davranışı Müslümanlar açısından Ö3 ve Ö9 yanlış ve kalleşçe olarak yorumlamışlardır. Firuz'un davranışını Haçlılar açısından Ö3, Ö8 ve Ö6 olumlu olarak yorumlamış. Firuz'un davranıŞını kendi açısındansa Ö3 intikam aldığ için mutlu Ö9 haklı olduğu için yaptığını söylemiştir. Ö8 de bu görüşlere katılmıştır. Öğrenciler açısından Firuz'un davranışı saf çıarcı eğilimdedir. Ö1 Firuz'un milli duyguları taştığından yanlış yaptığını ifade etmiştir.

Bundan sonra öğrenciler Kanit 12 ve 13 'ü incelemişler. Haçliların insan eti yeme davranışını hepsi abartılı bulmuşlardır. Bundan sonra Kanıt 14

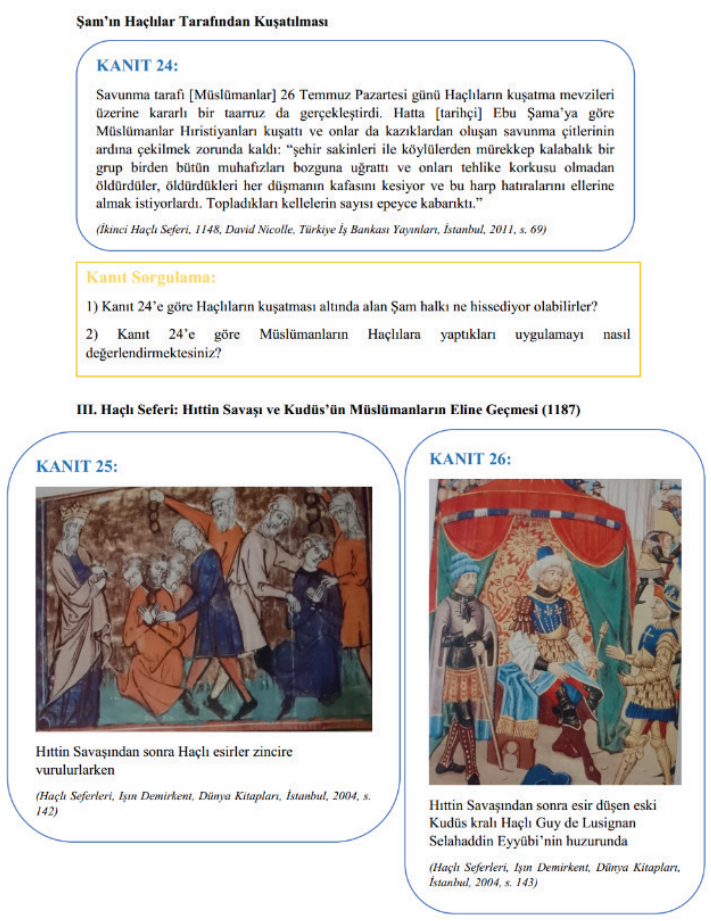

Şekil 8: Haçlı Seferleri Etkinlik Örneği incelenmiştir. Fatımilerin Kudüs'ü Haçlılara verme karşılığında Selçuklulara karşı ittifak yapma teklifini Ö3 yanlış bulmuş, Ö1 strateji Ö8 yapacak mecburiyet olarak değerlendirmiştir. Öğrenciler, Fatımilerin daha araçsal hareket ettiklerini söylemişlerdir. Kanıt 15, 16 ve 17'ye bakılmıştır. Haçlıların Mescid-i Aksa'da yaptıkları tahribatı değerlendiren öğrenciler Haçlılar hakkında olumsuz görüşler beyan ederler. Haçlıların insanlıktan çıkmış olduklarını, yaptıklarını artık eğlence için olduğunu söylemişlerdir. Öğretmen bu olayı ahlaki açıdan de- 
ğerlendirmelerini isteyince Ö8 "Müslümanlar Allah için yapıyor Haçlılar Tanrı için yapıyor. Ben anlamıyorum ikisi de aynı şey için... " ifadelerini kullanmıştır. Öğretmen din için böyle bir fiil yapılabilir mi sorusu üzerine Ö7 "kim din için insan yer ki? Hangimizin dininde insan yemek gibi bir şey var ki?" demiştir. Ö3 teslim olmuş insanlara bu şekilde muamele etmenin hem ahlaki hem de politik açıdan yanlış olduğunu belirtmektedir. Ö1, o insanların temelden itibaren bu eğitimi aldıklarından ötürü böyle yetiştiklerini dolayısıyla onlar için bunları yapmanın normal olduğunu söylemiştir. Ardından Kanıt 18, 19, 20, 21 ve 22 okunmuştur.

Öğrenciler, Haçlı lideri Bohemund'un fidye karşıllı̆̆nda Danişmend Gazi tarafından serbest bırakılmasını değerlendirmişler ve Ö3 ile Ö4 bunu yanlış bulmuşlardır. Öğretmenin Danişmend Gazi’ye hain diyebilir miyiz diye sorması üzerine Ö6, hayır diyerek cevaplamıştır. Ö8 bunu bir şey karşılığında yapmış demiştir. Ö1 ise kendi çıkarlarını gözetmiş kasti yapılan bir şey değil demiştir. Ö1 Danişmend Gazi’nin saf çıkarcı eğilimle hareket ettiğini ifade etmiştir. Tartışmanın devamında Ö8 ve Ö3 Danişmend Gazi’nin hile yapması gerektiğini söylemiştir. Kanıt 24'ü okuyan öğrencilerden Ö9, Ö7, Ö8, Ö3, Ö2 Müslümanların yaptıklarını az bile yapmışlar olarak değerlendirmişlerdir. Ö4 çocuk ve yaşlıların öldürülmesinin yanlış olduğunu demiştir. Ardından Kanıt 23 ve 26 gösterilmiştir. Burada Müslümanların Haçlılara gösterdiği muamelenin insanlık $\mathrm{m} 1$ yoksa aptallık mı olduğu sorulmuş ve Ö4 aptallık olarak değerlendirirken Ö1, Ö3, Ö8, Ö2, Ö9 insanlık olarak yorumlamışlardır. Bundan sonra Kanıt 28 ve 29 gösterilmiştir. Bu konuda Ö2 "Şöyle bir şey var. Bizim yaptığımız doğru gibi. Kelleyi kesip atıyoruz çünkü ölmesi lazım o zamana göre. Ama bunlar işkence yapıyor. $\mathrm{Bu}$ taraf işkence yapıyorsa bizim tarafın da işkence yapıp aynı şekilde karş11ık vermesi gerekiyor. Hafif kalmış bu yani” diyerek Müslümanların yaptıkların hafif bulmaktadır. Müslümanların Haçlılara yaptıkları misilleme hakkında konuşan öğrencilerden Ö1, Ö4, Ö3, Ö6 olanların yanlış olduğunu ve Müslümanların onları affetmeleri gerektiğini ifade etmişlerdir. Ancak Ö8 bunu bir misilleme olarak görmüş, Ö2 esir alsak da Bohemund gibi serbest kalıyor o yüzden en iyisi öldürmek demiştir. Müslümanlarla Haçlılar arasında sulh akdedildikten sonra Haçlıların, Hac yapabilmesi için Müslümanlar tarafından Kudüs şehrine alınması hadisesini Ö3 yanlış olarak yorumlamış ve hepsinin öldürülmesi gerektiğini söylemiştir. Ö1 olayı normal karşılarken Ö8 dini açıdan doğru demiştir. Ö9 bunu doğru bulmuştur. 


\section{Tartışma}

Kohlberg'in ahlaki ikilemleri temsil eden tarihi olaylar üzerine tasarlanan tarih dersinde çocukların değişim ve gelişimleri nitel bulgularlar ışığında incelenmeye çalışılmıştır. Konunun tarih alanıyla ilgili olmasından ötürü öğrencilerin ahlaki yargılarını etkileyen kimlik gibi önemli bir unsur da ortaya çıkmıştır. Ahlaki yargılarda tarihsel olay üzerinden okunan biz ve öteki kimliğinin etkili olduğu görülmektedir. Örneğin Müslüman kimliği Haçlı seferlerinin yorumlanmasında baskın olarak ön plana çıkmaktadır. Tarihi olaylarla kimlik arasındaki sıkı münasebet öğrencilerin ahlaki yargılarını da etkilemektedir (Pamuk, 2014).

Araştırma sürecinde öğrencilerin sadece tarihsel olayları kıstas alarak yaptıkları ahlaki muhakemeleri değil tarihsel olaylara konu olan şahsiyetlerin fiillerinin de öğrenciler tarafindan hangi ahlaki boyutta değerlendirildiği görülmüştür. Örneğin Yıldırım Bayezid'in kardeşi Yakup Çelebi'yi öldürmüş olması öldürme şeklinden ötürü öğrenciler arasında olumsuz karşılanmıştır. Yıldırım Bayezid'in kararı ve Yıldırım'ın ahlaki eğilimi tartışma konusu olmuştur. Tuğrul ve Çağrı Beylerin, Haçlıların, Danişmend Gazi'nin ve Fatih'in kararları üzerinden ahlaki yargılarına yönelik bazı yorumlamalar yapılmıştır. Bu açıdan çalışma hem öğrencilerin ahlaki yargılama süreçlerini incelerken hem de öğrencilerin etkinlikte geçen tarihsel karakterlerin ahlaki yargılamaları üzerine yorumlamalarını içermiştir. Bu bağlama uygun olarak MEB Tarih Öğretim Programının amaçlarının 3. maddesinde de "Türk, İslam ve Türkiye tarihinde rol oynamış önde gelen siyasi ve sosyal teşekküller ile önemli şahsiyetleri tanımaları" ibaresi bulunmaktadır (MEB). Çalışmada cinsiyet değişkeninin de fark yarattığ tespit edilmiştir. Süreç başında ve sonunda olduğu gibi süreç içerisinde de ahlaki yargılarda değişiklikler olmuştur. Bu akranlarının fikirlerinden etkilenme, farklı kanıtlar çerçevesinde pozisyon değiştirme gibi nedenlerden kaynaklanmaktadır. Örneğin Ö8 Selçukluların toprakları paylaştırması hakkındaki konu için akranlarının da etkisiyle fikrini süreç içerisinde değiştirmiştir. Bu Kohlberg'in ahlak kuramında sosyal çevrenin etkisiyle açıklanabilecek bir olgudur (Lind, 2000).

Tarih, ahlaki muhakemede meşrulaştırıcı bir unsur olarak da kullanılmıştır. Örneğin öğrencilerin, Berkyaruk ve Muhammet Tapar mücadelesinde kimin önce tahta çıktığını sorması, tarihsel öncelik sonralık ilişkisi içerisinde ahlaki yargılamalarını belirlemek için kullandıkları tarihsel bir meşruiyet zeminiydi. Ö1'in Haçlı seferinde din değiştirenleri eleştirmek için Tarık bin Ziyad'tan ve son Bizans imparatoru üzerinden örnekler vermesi geçmişten faydalanılarak 
güncel üzerine kurulan meşrulaştırıcı otoriteye örnektir. Böylelikle tarih, ahlaki yargıların sağlamlaştırılmasında kullanılmıştır (Heidbrink, 2000).

Öğrencilerin Kardeş katline ilişkin ahlaki yargılarının saf çıkarcı ve kanun ve düzen eğiliminde olduğu gözlenmektedir. Öğrencilerin kardeş katliyle alakalı olaylarda geçen tarihi şahsiyetlerin yorumlanmasında karakterlerin saf çıkarcı bir ahlaki muhakemeyle hareket ettikleri ama kardeş katli uygulamasının kanun ve düzen evresinde düşünüldüğü görülmektedir. Öğrencilerin kardeş katline çözüm üretmeye çalışan alternatifleriyse daha çok sosyal sözleşme eğiliminde değerlendirdikleri görülmektedir. Örneğin, Orhan Gazi ve Alaaddin Paşa ile Tuğrul ve Çağrı Bey arasındaki hadisede ortak yolun bir şekilde bulunması öğrencilerin çoğunu memnun etmiştir. Tuğrul ve Çağrı Beylerinse birbirleriyle yaptıkları anlaşmaya uymayacaklarını ve saf çıkarcı biçimde hareket edeceklerini söyleyenlerin çoğunluğu kız öğrencilerden oluşmaktadır. Yine şehzadelerin yakınında bulunan insanları dalkavukluk yapabileceklerini düşünen 3 kişiden 2'si kız öğrencidir. Dündar Bey'in Osman Gaziyle yaşadığı olayda Dündar'ın saf çıkarcı olduğunu söyleyen de yine bir kız öğrencidir. I. Murat'ın aslında tahtı Yıldırım Bayezid'e bıraktığı yönündeki kanıtın Enveri tarafından saf çıkarcı biçimde kullanıldığı iddiası da Ö4 ve Ö7'ye yani kız öğrencilere aittir. Yıldırım Bayezid'in kardeşi Yakup Çelebi'yi öldürmesi hadisesi haricinde kız öğrencilerin kardeş katli meselesinde tarihi şahsiyetleri genellikle saf çıkarcı hareket ettiklerini düşündükleri gözlemlenmektedir. Bu kız öğrencilerin erkeklere göre tarihi şahsiyetlerin karar ve ilişkilerindeki ahlaki muhakemelerine daha eleştirel ve güvensiz yaklaştıklarını göstermektedir. Tarihi karakterlerin kurduğu ilişkileri araçsallaştırabileceği şüphesi yorumlara yansımıştır. Tartışılan tarihi şahsiyetlerin erkek oluşu kadın öğrencilerin güncel kadın erkek tartışmaları üzerinden tarihi karakterlerin ahlaki yargılamalarını değerlendirdiğini düşündürebilir (Jodoin ve Samson, 1982).

Fatih devrine ait kaynaklardan olan Enveri'nin Düsturname-i Enveri adlı eserinden alıntılanarak öğrencilere sunulan kanıt bağlamında öğrencilerin tarihi kaynakları sorguladığı ve ahlaki bir yargılama içerisine girdikleri görülmektedir. Bu MEB Tarih Öğretim Programının 9. maddesinde belirtilen "Birincil ve ikincil kaynaklarda yer alan kanıtları belirleme, analiz etme, yorumlama ve değerlendirmeyi içeren tarihe özgü yeterlilik ve becerileri geliştirmeleri, edindikleri bilgilerin doğruluğunu ve geçerliliğini sorgulayarak kanttla desteklenen çıkarımlarda bulunmaları" amaciyla örtüşmektedir (MEB, 2018). 
Varlık vergisiyle ilgili çalışmadaysa öğrencilerin çoğunun, kanun ve düzen evresiyle saf çıkarcılık arasında gelip gittikleri görülmektedir. Bu konuya ilişkin bazı öğrencilerin ise sosyal sözleşmeye uygun olarak çıkarımlar yaptıkları görülmektedir. Bu bağlamda öğrencilerin ağırlıklı olarak Varlık vergisi toplanması gerektiği fikrine katıldığı ancak alt tartışmalarda bazı noktalarda ayrıştıkları görülmektedir. Ö1, Ö2, Ö6, Ö7 ve Ö8 kanun ve düzen evresinde görüş bildirmişlerdir. Varlık vergisinin etik boyutuyla alakalı alt tartışmalar öğrencileri ara yol arayışına sevk etmiştir. Ö7, insanların maddi durumuna göre vergi alınmasını teklif ederek grup içi tartışmalara sosyal adalet temelinde bir çözüm getirmek istemiştir. Onun bu görüşü sosyal sözleşme kapsamında değerlendirilebilir. Varlık vergisiyle alakalı bu alt tartı̧̧malar genel olarak Varlık vergisinin adaletsiz ama gerekli olduğu yönündedir. Örneğin Varlık vergisinin zenginlerden alınması ve vergi vermeyen zenginlerin Aşkale'ye çalışma kamplarına gönderilmeleri tartışılmıştır. Bu durum daha çok saf çıkarcı yorumlarla değerlendirilmiştir. Vergi verilmesi noktasında erkek öğrencilerin daha bireyselci düşündükleri ve saf çıkarcı eğilimde oldukları görülmektedir. $\mathrm{Bu}$ insanlığın tarıma geçmesiyle beraber başlayan sosyal iş bölümünün ve ataerkil, pederşahi toplum yapısının erkeğe atfettiği iktisadi mesuliyetlerin öğrenciler üzerindeki tezahürü olabilir. Buna kız öğrencilerden Ö7 daha toplumsalcı cevaplar vermiştir. Bireysel ve saf çıkarcı eğilimde olaya yaklaşan erkek öğrencilerden Ö2 grup içi tartışmalardan sonra fikrini değiştirerek daha toplumsalcı biçimde konuya yaklaşmıştır. Buna rağmen Ö9'un zenginlerden vergi alınması, varlık vergisinin adil olup olmaması, vergi mükelleflerinin Aşkale'ye gönderilmesi ve karaborsacılık faaliyetlerinde saf çıkarcı eğilimler göstermesi uygulamanın başından sonuna dek kararlılık göstermiştir.

Haçlı seferleri uygulamasındaysa saf çıkarcı ve bazen kanun ve düzen eğilimleri görülmektedir. Ancak kardeş katli uygulamasına benzer olarak tarihi olaylar içerisinde yer alan şahsiyetleri de değerlendiren öğrenciler onların saf çıkarcı davrandıkları konusunda ağırlıklı görüş bildirmişlerdir. Örneğin Kılıç Arslan'ın İznik'i kendi kaderine terk etmesi olayında Ö3, Kılıç Arslan'1 saf ç1karcı olarak betimlemiştir. Antakya şehrinin Haçlılara geçmesinde önemli rol oynayan Firuz'un davranışlarını yorumlayan öğrenciler onun saf çıkarcı olduğu yönünde neredeyse hem fikir olmuşlardır. Burada Firuz'un etnik kimliği ve tarihsel pozisyonu onun öğrenciler tarafından daha şiddetli tenkit edilmesine neden olmuştur. Danişmend Gazi’nin bir Müslüman olarak Haçlı lideri Bohemund'u fidyeyle serbest bırakmasını Ö1, saf çıkarcılık olarak değerlendirmiştir. Bu bağlamda konu itibariyle Haçlı seferleri kimliğe bağlı ahlaki muhakemenin daha sıklıkla yapıldığ bir alan olmuştur. 
İnceleme sonucunda elde edilen veriler doğrultusunda tarih derslerinin ahlaki muhakeme gelişimini destekleyebileceği ortaya konulmuştur. Dolayısıyla lise tarih derslerinin içeriğinde değerler eğitimine ilişkin uygulama kapsamının genişletilmesi mümkündür. Bunun yanı sıra değerler eğitimi bağlamında yapılabilecek çalışmalar için tarihin kullanımının da etkili sonuçlar verebileceği ifade edilebilir.

\section{Kaynakça}

Althusser, 1. (2016). İdeoloji ve devletin ideolojik aygıtları (A. Tümertekin, Çev.). İstanbul: İthaki Yayınları.

Balc1, A. (2011). Sosyal bilimlerde araştırma yöntem, teknik ve ilkeler. Ankara: Pegem Akademi.

Büyüköztürk, Ş. K1lı̧ Çakmak, E. Akgün, Ö. E. Karadeniz, Ş. Demirel F. (2012). Bilimsel araştırma yöntemleri. Ankara: Pegem Akademi.

Collingwood, R. G. (2019). Tarih tasarımı (K. Dinçer, Çev.). İstanbul: Ara Yayıncllik.

Creswell, J.W. (2013). Nitel, nicel ve karma yöntem yaklaşımları araştırma deseni (S. B. Demir, Çev.). Ankara: Eğiten Kitap.

Çiftçi, N. (2003). Kohlberg'in bilişsel ahlak gelişimi teorisi: ahlak ve demokrasi eğitimi. Değerler Ĕgitimi Dergisi, 1(1), 43-77.

Çinemre, S. (2012). Ahlak eğitimi bağlamında Kohlberg'in ahlak gelişim teorisi ve sorunları (Yüksek lisans tezi). Ondokuz Mayıs Üniversitesi Sosyal Bilimler Enstitüsü, Samsun.

Demircioğlu, İ. H. (2014). Tarih öğretiminde öğrenci merkezli yaklaşımlar. Ankara: Anı Yayıncilık.

Durkheim, E. (2014). Sosyoloji dersleri (A. Berktay, Çev.). İstanbul: İletişim Yayınlar1.

Ekşi, H. ve Katılmış, A. (2016). Uygulama örnekleriyle değerler eğitimi. Ankara: Nobel Yayıncilık.

Enright, R. ve Lapsley, D. ve Olson, L. (2011). Moral judgment and the social cognitive developmental research programme. Modgil, M. ve Modgil, C. (Ed.) Consensus and Controversy İçinde (s. 313-325). New York: Routledge.

Ferrer, F. (2014). Özgür eğitim modern okulun kökenleri (H. Şahin, Çev.). İstanbul: Pales Yayınları.

Freire, P. (2017). Ezilenlerin pedagojisi (D. Hattatoğlu ve E. Özbek, Çev.). İstanbul: Ayrıntı Yayınları. 
Giorgetti, F. (2016). Eğitim ritüelleri. İstanbul: Yeni İnsan Yayınevi.

Gündüz, M. (2013). Modern eğitimin doğuşu ve alternatif paradigmalar. Bayburt Üniversitesi Eğitim Fakültesi Dergisi. Eğitim Felsefesi Özel Sayı 1, 67-80.

Heidbrink, H. (2000). Moral judgment competence and political learning. Lind, G. ve Hartmann, H. A. ve Wakenhut, R. (Ed.) Moral Development and the Social Environment Studies in the Philosophy and Psychology of Moral Judgment and Education İçinde (s. 259-271). Precedent Inc. Chicago, Illinois.

Illich, İ. (2016). Okulsuz toplum (M. Özay, Çev.). İstanbul: Şule Yayınları.

Jodoin, L. M. ve Samson, J. M. (1982). Kohlberg's theory applied to the moral and sexual development of adults. Journal of Moral Education, 11(4), 247-258.

Kabapınar, Y. (2019). Kimlik belirleyen derslerde kanıt temelli öğrenme. Ankara: Pegem Akademi.

Kohlberg, L. (1963). Moral development and identification. H. W. Stevenson (Ed.) ve J. Kagan, C. Spiker (Collaborators) ve N. B. Henry, H. G. Richey (Eds.), Child psychology: The sixty second yearbook of the national society for the study of education, Part 1 (s. 277-332). National Society for the Study of Education; University of Chicago Press.

Kohlberg, L. (1964). Development of moral character and moral 1deology. M. L. Hoffman ve L. W. Hoffman (Ed.) Review of Child Development Research içinde (s. 383-433). Russell Sage Foundation New York.

Kohlberg, L. (1973). Continuities in childhood and adult moral development revisited. Erişim adresi: https://www.sciencedirect.com/science/article/pii/ B9780120771509500149

Kohlberg, L. ve Turiel, E. (1971). Morald and moral education. Gerald, S. L. (Ed.) Psychology and Educational Practice İçinde (s. 410-465). Scott, Foresman and Company Publisher.

Lind, G. (2000). the theory of moral-cognitive development: A socio-psychological assessment. Lind, G. ve Hartmann, H. A. ve Wakenhut, R. (Ed.) Moral Development and the Social Environment Studies in the Philosophy and Psychology of Moral Judgment and Education İçinde (s. 21-53). Precedent Inc. Chicago, Illinois.

MEB (2018). (2020, Haziran 2) Erişim adresi: http://mufredat.meb.gov.tr/Dosyalar/201822142524139-Tarih\%20d\%C3\%B6p.pdf

MEB. (2020, Haziran 2) Erişim adresi: http://mebk12.meb.gov.tr/meb_iys_dosyalar/34/39/749197/dosyalar/2015_02/09093609_degerleregitimi.pdf

Modgil, M. ve Modgil, C. (2011). Consensus and controversy. New York: Routledge. 
Neuman, L. W. (2013). Toplumsal araştırma yöntemleri nitel ve nicel yaklaşımlar (S. Özge, Çev.). Ankara: Yayın Odası.

Nichol, J. (1991). Tarih öğretimi (M. Safran, Çev.). Ankara: Çağrı Matbaacılık.

Pamuk, A. (2014). Tarih ve kimlik. İstanbul: Yeni İnsan Yayınevi.

Patton, M. Q. (2104). Nitel araştırma ve değerlendirme yöntemleri (M. Bütün ve S. B. Demir, Çev.). Ankara: Pegem Akademi.

Pearson, L. (2011). Social reasoning. Modgil. M. ve Modgil, C. (Ed.) Consensus and Controversy İçinde (s. 325-334). New York: Routledge.

Punch, K. F. (2005). Sosyal araştırmalara giriş nitel ve nicel yaklaşımlar (D. Bayrak, H. B. Arslan ve Z. Akyüz, Çev.). Ankara: Siyasal Kitabevi.

Rich, J. M. (2011). Morality, reason and emotions. Modgil, M. ve Modgil, C. (Ed.) Consensus and Controversy içinde (s. 209-220). New York: Routledge.

Rubin, K. H. ve Trotter, K. T. (1977). Kohlberg's Moral Judgment Scale: Some Methodological Considerations. Development Psychology, 13(5), 535-536.

Slavin, R. E. (2017). Eğitim psikolojisi kuram ve uygulama (G. Yüksel, Ed.). Ankara: Nobel Yayıncılik.

Stradling, R. (2003). 20. Yüzyılda Avrupa tarihini öğrenmek (A. Ünal, Çev.). İstanbul: Tarih Vakfi.

Sullivan, E. V. (2011). Kohlberg's stage theory as a progressive educational form for value development. Modgil, M. ve Modgil, C. (Ed.) Consensus and Controversy içinde (s. 233-243). New York: Routledge.

Üstel, F. (2004). Makbul vatandaşın peşinde: II. Meşrutiyet ten bugüne Türkiye'de vatandaş ě̆itimi. İstanbul: İletişim Yayınları.

Wilson, J. (2011). First steps in moral education: understanding and using reasons. Modgil, M. ve Modgil, C. (Ed.) Consensus and Controversy içinde (s. 223233). New York: Routledge.

Yıldırım, A. ve Şimşek, H. (2013). Sosyal bilimlerde nitel araştırmalarda yöntemleri. Ankara: Seçkin.

Yılmaz, O., Bahçekapılı, H. G. ve Sevi, B. (2019). Theory of moral development. T. K. Shackelford, V. ve A. Weekes-Shackelford (Ed.) Encyclopedia of Evolutionary Psychological Science İçinde (s. 93-98). Springer, Cham. 
Extended Abstract

\section{Moral Dilemma in Evidence Based History Teaching: Action Research}

Halil EKŞI, Professor.

Marmara University, Atatürk Faculty of Education, Turkey.

h.eksi70@gmail.com

https://orcid.org/0000-0001-7520-4549

H. Yavuz YAŞAR, Corresponding Author, Ph.D. Student. Marmara University, Atatürk Faculty of Education, Turkey.

yavuz_yasar1520@hotmail.com

https://orcid.org/0000-0003-0213-6502

Article Type: Research Article https://doi.org/10.34234/ded. 674957

Received Date: 14.01 .2020

Accepted Date: 22.05 .2020

Published Date: 25.06.2020

\section{Introduction}

The goals of Education have shown some changes with modernism. Having a behavioural pedagogical understanding, the school was built as a uniform, militarist, compulsory attendance-demanding, decentralised and synchronised structure (Gündüz, 2013; Giorgetti, 2016). The concept based on the God-servant relationship of the pre-Modern period has been replaced by the community-individual relationship (Durkheim, 2014). The criticisms as to the concept of school, which was instrumentalized by the government to build such a society, did not take long in coming. The Criticisms that the schools are being used as an ideological means to strengthen and legitimize the power have gained momentum (Althusser, 2016; Ferrer, 2014). Those who found behavioural ped- 
agogy to be the appropriate approach coined the service offered by the school as "banker education" (Freire, 2017). At the same time, the criticisms that the school has lost its main purpose by transforming into a form that trains the capitalist means of production and certifies individuals for this purpose have been made (Illich, 2016). History education has also been transformed into a shape that can serve the changing needs of the school and the world. With the modern paradigm, concepts such as the rise of nationalism and the establishment of nation states, war and army-nation understanding, that put human-nature relations on a rational plane have emerged. These concepts that emerged with the Modern paradigm were transferred to the masses through history lessons in schools. Thus, there was an attempt to create communities called nation, gathered around a common ideal. Every person who was part of the nation was a citizen of that society. There are duties that every citizen owes to her nation. The expected behaviours included; public space such as going to the military and dying for the country, paying taxes, keeping the environment clean, saving, being healthy, and getting up early. Thus, the definition of the nation formed was legitimized by myths taken from history instead of religion and this was spread to the masses through schools (Üstel, 2004). That understanding of what knowledge is and how it can be obtained began to change and this kind of history education was one of the causes of the great wars between nations that changed the aims of school, history and education. Accordingly, the student has started to be considered as a minor historian. The student who worked with the research methods of a historian evaluated the first and second hand historical sources presented to him. Therefore, a narrative understanding has been replaced by an understanding that analyses information and reveals its own interpretation. Evidence-based approach has emerged with this understanding that enables the student to complete his or her own construction process and treats him / her as a subject (Demircioğlu, 2014; Stradling, 2003; Nichol, 1991; Kabapınar, 2019). It has been important for the student to interact with their peers and learn in a collaborative manner.

In this approach that emerged in history education, individuals have established a relationship with history by being influenced by the many references they have. Culture, ideology, religion, socioeconomic and sociocultural structure, traditions and customs are some of the factors affecting this relationship. In addition, students have used their moral assessment skills effectively when interpreting the historical evidence presented to them. Therefore, with the evidence-based approach used in history education, students can be presented with 
evidences of many historical events and contribute to their development of moral reasoning skills. Indeed, this aspect of history education is closely related to Kohlberg's concept of moral dilemma, that he employed in his work on moral development.

In moral theory, Kohlberg examined morality from bottom to top on the pre-tradition level, the traditional level, and the post-tradition level. There are obedience and punishment together with pure self-interest in the pre-tradition level; law and order with the good child in the traditional level, and social contract and universal moral principles in the post-tradition level (Rubin ve Trotter, 1977). According to Kolhberg, people prefer the highest level of inquiry they can reach between these moral levels. It is possible that the individual's moral development can be fixed at some point as the individual's speed of passing steps can vary (Çinemre, 2012). Kohlberg treats morality as a cognitive process and states that an individual can make judgments that comply with universal criteria by using their cognitive abilities. According to him, moral consciousness and moral behaviour develop as a result of the individual's mutual interaction with society (Çiftçi, 2003). Therefore, Kohlberg states that the level of moral judgment that exists in the individual can develop with the complex social networks that it has established and the complex problems it faces in the public space (Y1lmaz, Bahçekapılı ve Sevi, 2019). For this reason, the development of the moral judgment process can be possible through cognitive processes, and this can happen internally rather than being externally. He interprets this as revealing in a Socratic style.

In this context, the concept of the moral dilemma put forward by Kohlberg with the current purposes of history education has similar contents at the point of being developed of students' moral judgment levels. Thus, it aims to compare students with many different historical/social events, leaving them in moral dilemma thus contributing to the cognitive moral reasoning processes in the face of contradictory situations. In a moral dilemma, different moral judgments in an event are presented to people's point of view. People's preferences are directly related to their moral judgments. Thus, it contributes in terms of having respect for different perspectives, lives, identities and the development of social democracy and empathy (Ekşi ve Katılmış, 2016). Kohlberg describes the goals of moral education as "mobilizing people's thinking abilities in accordance with their development and giving them more adequate and complex thinking skills to solve their moral problems."(Çinemre, 2012). In this context, the presenta- 
tion of historical events contributes to the understanding of moral questioning processes. In the examination, children's moral judgments were tried to be understood by giving historical events that may prepare the ground for moral dilemma discussions with evidence-based teaching. In this context, "How is the moral reasoning skills of the students affected according to Kohlberg's moral theory in the history lesson structured with evidence-based history teaching?" was determined as the problem question.

\section{Method}

The examination was conducted making use of qualitative research methods. The subject in qualitative research covers the process of in-depth analysis. Therefore, the use of qualitative research methods, as a process that depicts the findings, makes sense of the problem situation, and analyses it in depth, has been preferred (Yıldırım ve Şimşek, 2013; Neuman, 2013; Punch, 2005; Creswell, 2013; Patton, 2014, Balc1, 2011).

\section{Study Group}

The typical case sampling was based on within the scope of the purposive sampling (Yıldırım ve Şimşek, 2013). The examination was done with a group of 10 people consist of students of high school senior and college-preparatory.

\section{Data Collection Tools}

Observation and document analysis were used as data collection tools (Y1ldırım ve Şimşek, 2013). Fratricide, Crusades and Wealth Tax cases are presented to students in the form of evidence-based activity. During the activities, the students' state, movement, gesture and mimics were observed and the expressions were recorded with the voice recorder. The documents obtained from these records were examined. The researcher took some notes based on his observations about situations that occurred during the activity. The historical subjects that to be used during data collection was introduced through choosing and structuring 1st and 2nd hand visual and written sources, these sources were adapted in accordance with evidence-based history education. As a historical issue, fratricide, crusades and wealth tax were chosen, which could prepare the 
ground for the emergence of moral dilemma. The first practise was introduced by the subject of fratricide and it was implemented on 30 December 2018 with an activity lasting 75 minutes. Secondly, the subject of Wealth Tax was implemented on 11 January 2019 and lasted 72 minutes. The last practise was held on the Crusades on January 24, 2019 and lasted 70 minutes. Each activity was designed to cover an average of 2 course duration.

\section{Data Analysis}

After the recorded statements were transcribed, the transcription was evaluated within itself. Being objective as much as possible is required during this evaluation process. Content analysis method was applied in order to make research data as objective as possible. (Yıldırım ve Şimşek, 2013; Patton, 2014). The notes and records acquired through observation were evaluated and analysed.

\section{Findings}

The findings were examined under three headings in the context of fratricide activity example, wealth tax activity example and crusades activity example. When the findings were examined, it was observed that the moral dilemmas created over historical events during the activities were effective in being understood the moral judgments of the students. Students were able to change their minds or generate new ideas as a result of the process of discussions in the interactive environment created within the classroom. This shows us that moral reasoning may change or new perspectives may arise as a result of discussions on the historical evidence given. It is also understood that moral judgments given in some subjects differ visibly from time to time between male and female students. It has been observed that while male students made judgments about certain historical events in a more individual and pure-interest tendency, female students gave responses in a more social and law oriented about certain historical events. In accordance with the data obtained from the examination, it is understood that history lessons can support the development of moral reasoning. Therefore, it is possible to expand the scope of this practise that is related to values education in the context of high school history courses. In addition, it can be stated that the use of history in the context of values education can also yield effective results. 